Esta revista forma parte del acervo de la Biblioteca Jurídica Virtual del Instituto de Investigaciones Jurídicas de la UNAM

\title{
Apátridas saharauis en España: Europa y su memoria
}

\section{Stateless Sahrawi in Spain: Europe and their Memory}

\section{Manuel Jesús López Baroni*}

SUMARIO: I. Introducción. II. Cuestiones sobre nacionalidad. III. El estatuto de refugiado de los saharauis. IV. Cuestiones formales. V. Las directivas europeas. VI. Conclusiones.

* Doctor, licenciado en derecho y en filosofía, y profesor asociado de Filosofía del Derecho y Filosofía Política en la Universidad Pablo de Olavide, de Sevilla; miembro del Laboratorio de Ideas y Prácticas Políticas (LIPPO) de dicha universidad, forma parte del Grupo de Investigación Derechos Humanos. Teoría general, reconocido por el Plan Andaluz de Investigación de la Consejería de Innovación, Ciencia y Empresa de la Junta de Andalucía, España, e investiga sobre filosofía política española, materia en la que tiene diferentes publicaciones.

Artículo recibido el 9 de junio de 2013 Aprobado para publicación el 11 de septiembre de 2013 
Resumen: Durante la primera década de 2000 un grupo de saharauis ha obtenido el estatuto de apátridas en España. Para poder enfrentarse a esta cuestión los tribunales españoles se han visto obligados a revisar nuevamente una cuestión irresuelta, como es el abandono del Sáhara Occidental por parte de España en 1976 y la situación de desprotección internacional en que quedó la población nativa. Nos planteamos si los tribunales españoles han tratado de resolver jurídicamente un problema de naturaleza política, y en qué medida la concesión de la apatridia a los saharauis ha modificado la versión oficial o mayoritaria de lo sucedido con el Sáhara Occidental. Más allá del interés del caso concreto, entendemos que los argumentos, problemas y cuestiones generados por el estatus de los saharauis en España son extrapolables a otros colectivos en situaciones similares.

Palabras clave: apátridas, refugiados, asilo, nacionalidad, saharauis, descolonización, Unión Europea, España.

ABSTRACT: During the first decade of 2000 a group of Sahrawi has obtained the status of stateless in Spain. To be able to solve this issue the Spanish courts have been forced to check again a wavering question, since the abandon of Western Sahara by Spain in 1975 and the situation of international vulnerability in which the native population remained. We consider whether the Spanish courts have tried to solve legally a problem of political nature, and in what measure the concession from the stateless status to the Sahrawi has modified the official or majority version of what happened with the Western Sahara. Beyond the interest of the concrete case, we understand that the arguments, problems and questions generated by the status of the Sahrawi in Spain can be extrapolated to other groups in similar situations.

Descriptors: stateless, refugees, asylum, nationality, Sahrawi, decolonization, European Union, Spain.

RÉSUMÉ: Durant la première décennie de 2000 un groupe de Sahraouis a obtenu le statut d'apatrides à l'Espagne. Pour pouvoir résoudre cette question les tribunaux espagnols se sont nouvellement vus obligé de réviser une question irrésolue, comme c'est l'abandon du Sahara Occidental de la part de l'Espagne en 1975 et la situation de vulnérabilité internationale dans laquelle la population native est restée. Nous nous posons si les tribunaux espagnols ont juridiquement essayé de résoudre un problème de nature politique, et dans quelle mesure la concession de l'apatridie aux sahraouis a modifié la version officielle ou majoritaire du succédé avec le Sahara Occidental. Au-delà de l'intérêt du cas concret, nous entendons que les arguments, les problèmes et les questions générés par le statut social des Sahraouis en Espagne sont extrapolables à d'autres collectifs dans des situations similaires.

Mots-Clés: apatrides, réfugiés, asile, nationalité, Sahraouis, décolonisation, l’Union Européenne, Espagne. 


\section{INTRODUCCIÓN}

A lo largo de la primera década de 2000 un grupo de saharauis ha solicitado la condición de apátridas en España, país que durante casi un siglo detentó el Sáhara Occidental en calidad de colonia. La Administración española y la Audiencia Nacional rechazaron inicialmente las peticiones, pero finalmente el Tribunal Supremo las estimó, creando para ello una novedosa jurisprudencia entre 2007 y 2012. ${ }^{1}$ Lo más relevante de este hecho, más allá del carácter humanitario de la solución final, es que ha obligado a revisar el pasado colonial de España a la luz de los tratados internacionales en el contexto del nuevo milenio. Así, los argumentos de los saharauis y el Tribunal Supremo a favor de la apatridia, y de la Administración española y la Audiencia Nacional en contra, han reabierto heridas no cicatrizadas, revisitando, una vez más, lo que ocurrió cuando España dejó a su suerte el Sáhara Occidental y su población.

Por otro lado, los argumentos trascienden el caso particular de una población con su ex metrópoli al cuestionar conceptos en nada consolidados como los de refugiados o apátridas, así como los requisitos exigibles para alcanzar un estatuto u otro. Además, la Unión Europea de la que España forma parte ha publicado recientemente normas con objeto de crear un marco humanitario común para todos los países europeos en el tratamiento de los asilados. De esta forma, se superponen las Convenciones de Ginebra y Nueva York sobre Refugiados y Apátridas, ${ }^{2}$ respectivamente, con las directivas europeas sobre refugiados, ${ }^{3}$ que tam-

L Las sentencias no son muchas, pero no ocurre lo mismo con la casuística, que es amplia. Así, cada sentencia se ha ido enfrentando a los casos particulares hasta conformar un cuerpo de doctrina que analizaba todas las situaciones posibles. Por otro lado, las sentencias del Tribunal Supremo español se han dictado entre 2007 y 2012 al resolver recursos de casación interpuestos contra diferentes sentencias de la Audiencia Nacional española, que fallaba siempre en contra de las peticiones de los saharauis.

2 Convención de Ginebra sobre Refugiados del 28 de julio 1951 y Protocolo del 31 de enero 1967, a los que se adhirió España por Instrumento de 22 de julio 1978, RCL 1978\2290; Convención de Nueva York sobre Apátridas del 28 de septiembre 1954, a la que se adhirió España por Instrumento del 24 de abril 1997, RCL 1997\1709.

Directivas 2004/83/CE, del 29 de abril, LCEur 2004\3082, y 95/UE, del 13 de di- 
Esta revista forma parte del acervo de la Biblioteca Jurídica Virtual del Instituto de Investigaciones Jurídicas de la UNAM

bién tratan cuestiones de los apátridas. El fruto de esta disparidad de normas se puede observar con toda su crudeza en que, si cruzamos la reciente jurisprudencia del Tribunal Supremo español con la jurisprudencia del Tribunal de Justicia de la Unión Europea sobre refugiados y apátridas en países europeos, se generan un sinfín de preguntas sin resolver.

España se retiró de la colonia africana del Sáhara Occidental a principios de 1976, después de casi un siglo de presencia en dicho territorio. El contexto en el que se produjo esta retirada fue el de la inminente muerte del dictador Franco, en el poder tras una cruenta guerra civil, los deseos de la población española de iniciar la transición hacia la democracia después de cuarenta años de dictadura, y el anhelo marroquí por anexionarse el territorio.

Entre la agonía del dictador y la inminente transición española se generó un enorme vacío de poder, lo que aprovechó Marruecos para invadir el territorio. España renunció al Sáhara Occidental retirando a sus tropas y dejando desprotegida a la población nativa, lo que provocó su desplazamiento masivo a los campos de refugiados del vecino país de Argelia mientras sus escasas fuerzas entablaban una guerra abierta contra Marruecos.

La situación actual, después de más de treinta años, es de punto muerto. Como señalaba Rosa Riquelme, el Sáhara Occidental es hoy el único territorio no autónomo del continente africano pendiente de descolonización. ${ }^{4}$ Una parte sustancial de los saharauis viven en campos de refugiados en Argelia bajo cobertura de la ONU, esperando un referéndum que decida si finalmente el Sáhara Occidental se integrará en Marruecos o será un Estado independiente. La desesperanza, el agotamiento, la política de los hechos consumados y la ausencia de una voluntad internacional real para solucionar el conflicto han gangrenado la situación.

ciembre, LCEur 2011 \2173, que establecen normas mínimas relativas a los requisitos para el reconocimiento y el estatuto de nacionales de terceros países o apátridas como refugiados o personas que necesitan otro tipo de protección internacional y al contenido de la protección concedida.

4 Riquelme Cortado, Rosa, "Marruecos frente a la (des)colonización del Sáhara Occidental”, Anuario Mexicano de Derecho Internacional, vol. XIII, 2013, pp. 205-265. 
Esta revista forma parte del acervo de la Biblioteca Jurídica Virtual del Instituto de Investigaciones Jurídicas de la UNAM

Estudiaremos a continuación los diferentes argumentos que se han empleado en este debate, en esencia, si los saharauis no podían obtener el estatuto de apátrida porque en realidad eran refugiados bajo cobertura de la ONU, o nacionales españoles, marroquíes, argelinos o incluso del propio Estado saharaui. ${ }^{5}$ Además, trataremos de contextualizar este debate haciendo referencia a la normativa y la jurisprudencia europea sobre este tema. Tras el análisis de los argumentos formularemos las conclusiones, en esencia, si el Tribunal Supremo español ha tratado de resolver jurídicamente un problema de naturaleza política y cuáles son los efectos, más allá del caso saharaui, de sus sentencias.

\section{CUESTIONES SOBRE NACIONALIDAD}

Una de las principales cuestiones objeto de controversia en los tribunales españoles ha sido si los saharauis poseían alguna nacionalidad que pudiera impedir la concesión de la apatridia. Al debatir sobre este tema han reaparecido cuestiones largo tiempo enquistadas, como si los saharauis fueron alguna vez españoles de pleno derecho o no, si éstos estaban obligados a aceptar la nacionalidad que interesadamente les ofrecía el Estado invasor, Marruecos, o cuál es el estatus de los miembros de un Estado no reconocido por toda la comunidad internacional, como ocurre con la República Árabe Saharaui Democrática. Es lo que analizaremos a continuación.

\section{La nacionalidad española}

Al solicitar el estatuto de apatridia en España los saharauis han obligado a los tribunales a revisar una vez más cuál fue el estatuto alcanzado por su

La Administración española, siguiendo las órdenes de quien gobierna, denegó la condición de apátrida de los saharauis, imaginamos que para evitar posibles migraciones masivas. El abogado del Estado ha estado recurriendo incluso cuando ya la Audiencia Nacional acogía los argumentos del Tribunal Supremo. Así, la sentencia del Tribunal Supremo de 11 mayo 2012, RJ $\backslash 2012 \backslash 6667$, denegó el recurso de casación interpuesto por el Estado contra la sentencia de la Sección Quinta de la Audiencia Nacional del 8 de junio de 2011 que aceptaba la condición de apátrida de un saharaui. 
población durante la historia de la colonización del Sáhara Occidental. El motivo técnico es obvio: para poder ser apátrida es necesario no ser nacional de ningún Estado. Pero el caso español añade complejidad a esta cuestión, ya que una de las reivindicaciones históricas de los saharauis ha sido precisamente la nacionalidad española, debido a su particular historia, hasta el punto de que diez años antes de que aparecieran las primeras sentencias sobre apatridia el propio Tribunal Supremo concedió dicha nacionalidad a dos saharauis, generando expectativas en el resto de la comunidad. La pregunta central que aletea es si alguna vez, a lo largo de los casi cien años de historia en común, los saharauis fueron españoles en igualdad de condiciones con los habitantes de la metrópoli, dado que nunca hubo un acto formal de concesión de la nacionalidad, pero tampoco existió la revocación expresa o declaración de nulidad de ésta.

Para abordar esta pregunta es necesario dividir la historia española del Sáhara Occidental en tres etapas: colonización, provincialización y descolonización. Como observaremos, el problema lo provoca la segunda, la etapa de provincialización, ya que generó la ficción de que los saharauis eran españoles a todos los efectos.

\section{A. Primera etapa: colonización}

En esta primera fase, que abarca desde su ocupación en 1884 hasta la década de 1950, el Sáhara Occidental es una mera colonia española. Los saharauis ostentarían, al igual que ocurría con otros países europeos y sus colonias, el estatuto de súbditos de los españoles (ciudadanos-súbditos, como mucho). Ahora bien, dado que Marruecos disputa este territorio actualmente a los propios saharauis, la única pregunta que suscita esta etapa es si el Sáhara Occidental era terra nullius, esto es, tierra sin dueño, en el momento de la ocupación por parte de los españoles, lo que indirectamente acarrearía consecuencias sobre la nacionalidad de los saharauis.

Pues bien, el Tribunal Supremo zanjó con claridad esta cuestión, apoyándose para ello en el Dictamen que emitió el 16 de octubre de 1975 la Corte o Tribunal de Justicia Internacional como respuesta a las cuestiones solicitadas por la XXIX Asamblea de las Naciones Unidas (Resolución 3292). Dicho dictamen partía de la tesis de que el Sáhara no 
era un territorio sin dueño y que España lo ocupó mediante pacto con los jefes tribales, "por eso, en su decreto de 26 de diciembre de 1884, el Rey de España proclamó que estaba tomando el Río de Oro bajo su protección sobre la base de acuerdos concertados con los jefes de las tribus locales". ${ }^{6}$

Este punto de partida fue el que llevó al Tribunal Supremo a conceder la apatridia por primera vez en 2007, ya que en su opinión este pacto demostraba que España "ya desde su origen nunca consideró españoles a los saharauis". ${ }^{7}$ Sin embargo, como observaremos a continuación, esta conclusión no es tan evidente como pueda parecer, ya que contradecía otras sentencias del propio tribunal que años antes se había pronunciado en un sentido bien diferente.

\section{B. Segunda etapa: provincialización}

Este periodo, que podemos acotar entre 1950 y 1960, es de una naturaleza extraña, ya que se caracteriza por el intento de España de asimilar, integrar o considerar sus colonias parte del territorio español en las mismas condiciones que el resto de la metrópoli. Aunque el sentir común es que nunca se llegó a lograr, no tanto por falta de voluntad del régimen sino porque el contexto internacional hacía insostenible esta pretensión, lo cierto es que hubo actuaciones ambiguas de efectos a largo plazo.

Dada la brevedad que le podemos dedicar a este tema, sólo vamos a señalar los dos extremos de la argumentación. Por un lado, el informe del Consejo de Estado sobre Guinea Ecuatorial emitido el 20 de junio de 1968, que sostenía que, incluso aunque fuese cierto que en noviembre de 1958 y agosto de 1959 España rechazó informar a las Naciones Unidas sobre sus territorios en África porque negaba que fueran Territorios No Autónomos, desde 1961 se enviaba periódicamente esa información, reconociendo implícitamente que eran Territorios No Autónomos, es decir, colonias. ${ }^{8}$ Ahora bien, en el otro extremo podemos releer

6 Sentencia del Tribunal Supremo, Sala Primera, del 28 de septiembre de 1998, $\mathrm{RJ} \backslash 1998 \backslash 8257$.

Sentencia del 20 de noviembre de 2007 (RJ 2008, 6615) (RC 10503/2003).

8 Dictámenes del Consejo de Estado sobre Guinea (Dictamen núm. 36017, del 20 de junio 
el testimonio privilegiado del que fuera embajador y miembro de la delegación española en las Naciones Unidas aquellos años, ${ }^{9}$ Jaime de Piniés y Rubio, acompañado de abundante información, y observar que entre 1957-1960 el gobierno español pretendió integrar en la metrópoli, en igualdad de condiciones con el resto del territorio originario, a las colonias de Ifni, Guinea Ecuatorial y el Sáhara Occidental. ${ }^{10}$ El

de 1968), y sobre Ifni (Dictamen 36227, de 7 de noviembre de 1968), Recopilación de doctrina legal, 1967-1968, Madrid 1971, pp. 21-31; y Recopilación de doctrina legal 1968-1969, Madrid 1972, pp. 613-620.

9 Jaime de Piniés y Rubio formó parte de las delegaciones españolas en las Asambleas de Naciones Unidas XI hasta la XL, salvo la XXVIII, por ser embajador en Londres, y embajador en Naciones Unidas desde 1968 hasta 1972 y desde 1973 hasta 1985. Fue también el último presidente de la Comisión para la Información sobre Territorios No-Autónomos, creada por la III Asamblea General de la ONU en 1949. Piniés y Rubio, Jaime, La descolonización española en las Naciones Unidas. Guinea Ecuatorial (Fernando Poo y Río Muni), Ifni, Sáhara Occidental, Gibraltar y las Naciones Unidas, Madrid, Centro de Estudios Políticos y Constitucionales, 2001.

${ }^{10}$ El relato no deja lugar a dudas. Así, Jaime de Piniés narra cómo los incorporados a fines de 1955, España y Portugal, rechazaban la obligación de transmitir información sobre los Territorios No Autónomos que administraban. En el caso de España porque "dado el carácter de provincias que tenían estos territorios, el Gobierno no se consideraba obligado a transmitirla” (p. 8). Recuerda asimismo cómo Francia consideraba Argelia como territorio metropolitano. En este contexto, continúa relatando que se "encontraba en Madrid en julio de 1957 y tuve oportunidad de expresar mi opinión cuando se preparó en la Dirección de Organismos Internacionales un informe que hacía referencia a otro anterior de marzo, en el que se llegaba a la conclusión de que resultaba obligatorio suministrar la información solicitada, pero el 19 de mayo, la Dirección General de Marruecos y Colonias opinaba lo contrario basándose en que como la zona norte de Marruecos había sido integrada en Marruecos independiente, los territorios españoles de Ifni, El Sáhara, Guinea Insular y Continental, Ceuta y Melilla y dependencias «constituían verdaderas provincias españolas de régimen especial» y se inclinaba decididamente a que se contestara al Secretario General que «España no posee territorio alguno de los comprendidos en el capítulo XI, XII y XIII de la Carta» ... Finalmente, prevaleció el criterio de ordenar a nuestra Misión el que se rehuyera todo envío de información y para ello se harían las reformas de nuestra legislación interna, como así se hizo” (p. 20). Sigue afirmando que el Ministerio de Asuntos Exteriores era favorable a la tesis de la Delegación española, en el sentido de que se debía mandar dicha información, pero al final, sin duda por presión del Gobierno de Lisboa, "se dio marcha atrás y se instruyó a nuestra Delegación que debíamos seguir negando la existencia de Territorios No-Autónomos bajo nuestra administración y que oficialmente la Presidencia del Gobierno, que estaba redactando un proyecto de contestación al Secretario General de las Naciones Unidas, fijaría nuestra posición teniendo en cuenta que los territorios africanos españoles no son Territorios No-Autónomos sino que están integrados en España... De esta forma se preparó la Ley que en 1959 había de calificar a nuestros territorios como «provincias españolas»... Así, y mediante este simple 
Dictamen del Consejo de Estado es de 1968, es decir, que reinterpreta el pasado a la luz del presente de ese momento ("nunca dejaron de ser colonias”), pero los textos de esos años, 1957-1960, citados por el embajador, expresan claramente la voluntad de equiparar las colonias a las provincias metropolitanas. Es más, incluso cuando en una fecha difícil de determinar a lo largo de 1961 se reconoce que estamos ante Territorios No Autónomos, el propio Jaime de Piniés afirmó ante el Comité de Descolonización, en 1963, que la fase de provincialización había tenido por objeto "igualar esos territorios al resto de las provincias españolas en el disfrute de los mismos derechos".

procedimiento se trataba nada menos que de sustraer el proceso descolonizador, como si contáramos con el decidido deseo de su población de mantenerse adherida a España” (p. 20). Además, el ministro de asuntos exteriores, Castiella, remitió al Secretario General una nota (documento A/C.4/385) en la que literalmente afirmaba que "España no posee Territorios No-Autónomos, pues lo que están siendo sometidos a su soberanía tienen la consideración y clasificación de provincias españolas, con arreglo a la legislación vigente. En consecuencia, el Gobierno español no se siente incluido en el artículo 73 de la Carta de las Naciones Unidas referente a Territorios No-Autónomos sin existencia legal dentro de la organización administrativa española. Sobre la situación de las provincias españolas en África...” (p. 21). Según Jaime de Piniés, fue el embajador español en Naciones Unidas en aquellos momentos, Lequerica, quien consideró insostenible no reconocer la existencia de Territorios No Autónomos, contraviniendo incluso las instrucciones que del Ministerio de Asuntos Exteriores, todavía en noviembre de 1960, le obligaban a sostener que dichos territorios no existían (p. 34). Al confirmar por su cuenta y riesgo Lequerica ante la ONU la existencia de dichos territorios No Autónomos, el propio Ministerio ofreció a Portugal desautorizar públicamente a la Delegación española en la ONU, pero Salazar estimó que no era necesario llegar a tanto. Lequerica dejó el cargo por motivos de salud y fue asumido por Jaimé de Piniés, a quien se le indicó que "había que evitar a toda costa cualquier clase de discurso o declaración que no fuera puramente formularia", y que afirmara que "nuestros territorios no podían ser considerados como Territorios No-Autónomos" (Piniés dice que esas instrucciones las recibió el 21 de abril de 1960, pero creo que es un error y debe ser de 1961 — nota del autor de este artículo-). El propio Jaime de Piniés, formando parte del Comité de Descolonización, en 1963, informó a dicho organismo en estos términos: "Luego de este examen me ocupaba de nuestros territorios, de los que decía que sólo en los últimos años nos habíamos cuidado de desarrollarlos en sus diversos aspectos, pero abundaba en la idea que había prevalecido en nuestros textos legales: la consideración de colonia. Del término de provincia que se había estado utilizando, explicaba que me había visto obligado en la Comisión a señalar que no tenía más que un significado jurídico: igualar esos territorios al resto de las provincias españolas en el disfrute de los mismos derechos (las cursivas son mías) pero en modo alguno podía tener otro ya que habría sido un contrasentido una vez que habíamos aceptado el principio de la autodeterminación (lo había explicado en la Comisión de Territorios No-Autónomos y en la IV Comisión de 1962)" (p. 83). Piniés y Rubio, Jaime, op. cit. 
Esta revista forma parte del acervo de la Biblioteca Jurídica Virtual del Instituto de Investigaciones Jurídicas de la UNAM

¿De qué forma se trasladan estas posiciones a las sentencias del Tribunal Supremo? Pues podemos constatar cómo ambas son recogidas en las resoluciones del alto tribunal. En efecto, cuando a lo largo de la década de los noventa, ya en democracia, dos saharauis solicitan la nacionalidad española, la Administración denegó las peticiones alegando que los saharauis nunca habían llegado a ser propiamente españoles. ${ }^{11}$ Para resolver este asunto, el Tribunal Supremo dictó dos sentencias, una en 1998 (Sala de lo Civil), y otra en 1999 (Sala de lo Contencioso Administrativo), de gran eco mediático, ya que concedieron la nacionalidad española a los dos solicitantes aunque fuese por motivos diferentes y no extrapolables al resto de la comunidad. Pero lo que interesa para nuestro caso es cómo analizaron las cuestiones referidas a la naturaleza tanto del territorio como de la población. Es preciso tener presente en todo momento que ambas sentencias se dictan por dos Salas del mismo tribunal, la Civil y lo Contencioso Administrativo, es decir, que se analiza el mismo problema a la luz de dos partes diferentes del ordenamiento jurídico español, lo que en parte explica, aparte de la complejidad del tema ("mandan los muertos", comentó el fiscal del caso, dado lo anacrónico de la situación), ${ }^{12}$ las contradicciones y diferencias entre ambas resoluciones a pesar de dictarse con un año de diferencia.

Pues bien, la sentencia de 1998 (Sala de lo Civil) ${ }^{13}$ continúa la tesis narrada por el embajador Jaime de Piniés, sosteniendo que la provincialización provocó que las colonias fuesen tratadas:

Como una extensión del territorio metropolitano, o sea, territorio español, sin acepciones, con todas las vinculaciones políticas determinantes de la referida con-

11 En concreto, la Dirección General de Registros y del Notariado las denegó afirmando que "el Sáhara nunca fue territorio español a efecto de adquisición de la nacionalidad española... ni sus habitantes fueron españoles en sentido estricto, sino que aquel territorio se entendía sometido a la soberanía española, y sus habitantes súbditos españoles, pero no nacionales”.

12 Concluyendo, refiriéndose a las Cortes franquistas en las que podían participar los saharauis en igualdad de condiciones con los españoles, que "aquellas Cortes orgánicas y las llamativas indumentarias que lucían los llamados Procuradores en Cortes, desde la chaqueta blanca con camisa azul hasta la chilaba, sea de inevitable aunque tal vez no agradable evocación en la vista de este recurso". Tribunal Supremo, Sala de lo Civil, sentencia núm. 1026/1998 del 28 octubre, RJ $\backslash 1998 \backslash 8257$.

13 Tribunal Supremo, Sala de lo Civil, sentencia núm. 1026/1998 del 28 octubre, $\mathrm{RJ} \backslash 1998 \backslash 8257$. 
cepción que, sin duda, se proyectaron, como corolario obligado, en la población saharaui y, en su condición de nacionales españoles. Ilustres administrativistas enseñaron que la «provincialización» elevaba dichos territorios al rango de territorio nacional.

El alto tribunal asumió que esta asimilación se hacía completamente al margen del derecho internacional, hasta el punto de hacer propia otra sentencia del propio Tribunal Supremo de 1977, justo después de la retirada española del Sáhara Occidental, que decía literalmente: "No debe, pues, extrañar que el Tribunal Supremo (Sala Primera, Sentencia de 22 febrero 1977 [RJ 1997\612]), declarara que, en la fecha del nacimiento que se enjuiciaba, El Aaiun «era una provincia española y la palabra España comprendía todo el territorio nacional»”. ${ }^{14}$

Sin embargo, la sentencia de 1999, dictada por la Sala de lo Contencioso Administrativo, ${ }^{15}$ acoge la opinión manifestada por el Consejo de Estado en sus dictámenes sobre Guinea Ecuatorial e Ifni (que a su vez inspiraron la Ley de Descolonización del Sáhara de 1975, de ahí su relevancia),${ }^{16}$ esto es, que las colonias africanas nunca formaron parte

14 "En cualquier caso de lo que no cabe duda, con referencia a la «nacionalidad» de los saharauis, durante el plazo de la tutela de nuestro Estado sobre el territorio del Sáhara Occidental, es que ésta fue la española (de «españoles indígenas», habla alguna disposición), pues resulta evidente, conforme a las reglas generales del Derecho de la nacionalidad, que «los naturales del territorio colonial carecen de una nacionalidad distinta de los del Estado colonizador, dado que no poseen una organización estatal propia»”. Tribunal Supremo, Sala de lo Civil, sentencia núm. 1026/1998 de 28 octubre, RJ\1998\8257.

15 Así, el Tribunal Supremo, en su sentencia de 1999 (Tribunal Supremo, Sala de lo Contencioso-Administrativo, Sección 6a., sentencia del 7 noviembre 1999, RJ $2000 \backslash 849$ ), asumió como propia la doctrina que distinguía por un lado el territorio metropolitano y el territorio colonial, y por otro el territorio español, que sería la suma del territorio metropolitano y el colonial, y el territorio nacional, que es el metropolitano, es decir, el "espacio vinculado, infungible, inalienable, imprescriptible, esencial”. Tras esta clasificación el Tribunal Supremo revertió el estatus del Sáhara Occidental afirmando que la equiparación a la provincia que se realizó entre 1950 y 1960 no fue una verdadera asimilación política sino una forma de mejorar la administración colonial, de forma que el Gobernador general de la provincia, a pesar de ostentar el mismo nombre que en el resto de provincia españolas, era en realidad un "Gobernador colonial”. En esta revisión a posteriori del estatuto del Sáhara el propio Tribunal Supremo llegó a cuestionar el rango de las leyes que aprobaron la provincialización del Sáhara, afirmando que la conversión de un territorio colonial en territorio nacional debía ser aprobada por las Cortes, aunque fuesen las franquistas, y eso no se hizo.

${ }^{16}$ El preámbulo de dicha ley recogía la tesis de los Dictámenes del Consejo de Estado, 
Esta revista forma parte del acervo de la Biblioteca Jurídica Virtual del Instituto de Investigaciones Jurídicas de la UNAM

de España, alineándose de esta forma con quienes sostenían que el Sáhara Occidental nunca pasó de ser mera colonia, es decir:

Territorio de libre disposición, fungible, alienable, prescriptible, accidental (no esencial), protegido con protección ordinaria, cuantitativamente valorable por cuanto se le puede tomar (y de hecho se le toma) como magnitud física (remitiendo por ello a ideas concretas y hasta, en su caso, groseramente crematísticas). ${ }^{17}$

Pues bien, partiendo de estas contradictorias premisas, la pregunta clave es cuáles son los efectos de la política seguida en esos años, 19571960 , no ya sobre el territorio sino sobre los saharauis, ${ }^{18}$ ya que esta eta-

afirmando que: "El Estado español ha venido ofreciendo, como Potencia administradora, plenitud de competencias y facultades sobre el territorio del Sáhara, que durante algunos años ha estado sometido, en ciertos aspectos de su administración, a un régimen particular con analogías al provincial y que nunca ha formado parte del territorio nacional. Próximo a culminar el proceso de descolonización de dicho territorio, de conformidad con lo establecido en la Carta de las Naciones Unidas, procede promulgar la norma legal adecuada para llevar a buen fin dicho proceso, y que faculte al Gobierno para adoptar las medidas al efecto”. La ley de Descolonización del Sáhara fue aprobada el 19 de noviembre de 1975 y publicada en el BOE del 20 de noviembre de 1977.

17 Tribunal Supremo (Sala de lo Contencioso-Administrativo), Sección 6a., sentencia del 7 noviembre 1999 , RJ $\backslash 2000 \backslash 849$.

${ }_{18}$ La lectura de uno de los dictámenes del Consejo de Estado provoca un efecto contrario al que pretendía, y es que si se podía abandonar territorio español aunque constitucionalmente formaran parte del concepto de "integridad territorial”, con más razón se podría incorporar territorio no español sin necesidad de grandes formalidades normativas: "Este mismo criterio encuentra su ayoyo en el examen de la historia jurídico-política española y de los precedentes inmediatos que de la descolonización pueden encontrarse en ella: la emancipación americana, la cesión de Cuba, Puerto Rico y Filipinas a los Estados Unidos y la venta a Alemania de las restantes posesiones españolas en el Pacífico, casos en los que, como en el presente, se trata de ceder territorios bajo soberanía española. Más aún, en lo que hace a las posesiones americanas, los territorios cedidos en 1898 y 1899 se trataba de territorios que las Constituciones de la época consideraban como parte integrante del nacional (artículos 1 o. y 10 de la Constitución de 1812, en vigor el 4 de diciembre de 1836, al autorizarse por las Cortes el reconocimiento de la independencia de las Repúblicas americanas, y título XIII de la Constitución de 1876, en vigor en 1898 y 1899), sin que ello empeciese a que la renuncia de la soberanía española sobre los mismos se hiciese por vía de acuerdo, previa autorización de las Cortes, como fue el caso del Decreto de las Cortes Constituyentes de 4 de diciembre de 1836, como verdadera “Acta de Emancipación” de la Ley de 16 de septiembre de 1898 autorizando a Puerto Rico, Filipinas e Isla de Guam, que permitió la ratificación del Tratado de Paz de 10 de diciembre de 1898, y la Ley de 24 de junio de 1899, autorizando al Gobierno 
pa de provincialización de las colonias fue acompañada de una política de equiparación de su población con respecto a la metropolitana. Dos datos destacan por encima de todo, el hecho de poder participar en las Cortes franquistas en igualdad de condiciones que el resto de los españoles y la posibilidad de ser funcionario de la administración, algo sólo permisible si se es nacional español. ${ }^{19}$ Décadas después se han intentando buscar numerosos elementos distintivos, como si sus carnés de identidad eran ligeramente diferentes a los del resto de los españoles, ${ }^{20}$ o que sus provincias no eran administrativamente equiparables a las metropolitanas, pero eso es una racionalización a posteriori, que podemos encontrar tanto en artículos doctrinales ${ }^{21}$ como en el propio Tribunal

para ceder a Alemania las Islas Carolinas, Palao y Marianas y que permitió la ratificación del Convenio hispano-alemán de 30 de junio de 1899 y según lo previsto en el artículo 55 de la Constitución a la sazón vigente, de 1876". Dictámenes del Consejo de Estado sobre Guinea (Dictamen núm. 36017, de 20 de junio de 1968, Recopilación de doctrina legal, 1967-1968, Madrid 1971, pp. 21-31.

19 Juan Soroeta recuerda que algunos saharauis han llegado a cobrar sus pensiones de la Administración española en los campos de refugiados, y que eso sólo es posible si se es español: "En el caso que nos ocupa y, ante el hecho consolidado del gran número de saharauis que después de haber sido funcionarios fueron desposeídos de tal condición, sólo cabría considerar razonable como causa para ello la pérdida de la nacionalidad, lo que conllevaría la consideración de que los habitantes del Territorio efectivamente poseyeron la nacionalidad española”, Soroeta Liceras, Juan, "La problemática de la nacionalidad de los habitantes de los territorios dependientes y el caso del Sáhara Occidental, Análisis de la sentencia del Tribunal Supremo de 28 de octubre de 1998”, Anuario de Derecho Internacional, núm. 15, 1999, pp. 645-676.

20 En contra de que alguna vez adquirieran la condición de españoles se sitúa Mónica Guzmán, quien afirma que el registro en el que se inscribían los saharauis era especial, y no se trasladaban sus inscripciones al Registro Central, y el Documento Nacional de Identidad tenía características distintivas con respecto a las del resto de la población española. Sin embargo, la autora reconoce que sí se creó la ficción de que eran españoles. Guzmán Zapater, Mónica, "Descolonización y nacionalidad. El caso saharaui (En torno a la STS de 26 de octubre de 1998)", Revista de Derecho Privado, marzo de 2000, pp. 200-210, y en "RDGRN de 23 de marzo de 1999. Descolonización y nacionalidad: el caso saharaui. Consolidación de nacionalidad”. Cuadernos civitas de jurisprudencia civil, enero-marzo de 2000, pp. 15-27. Por mi parte, estimo que el elemento clave a medias entre la ficción y la no nacionalidad es que los saharauis tenían en las Cortes franquistas los mismos (escasos) derechos que el resto de la población española, es decir, que para ser un espejismo estuvo bastante logrado.

${ }^{21}$ Se podría matizar recordando que los saharauis pudieron crear un partido pro-español como el Partido de Unión Nacional Saharaui, algo vedado, la creación de partidos, a los españoles, pero lo relevante para nuestro caso es que metropolitanos y no metropolitanos estaban equiparados en sus derechos. 
Supremo. Lo cierto es que en aquellos años se creó una ficción, y en derecho las ficciones tienen consecuencias. Una cosa es que a lo largo de 1960 España tuviera que rectificar ante la comunidad internacional su voluntad de integrar las colonias en la metrópoli, y otra muy diferente es que entre 1957 y 1960 esos territorios, jurídica y fácticamente, no hubiesen formado parte, junto a su población, del territorio nacional. La clave está en qué medida la forzada y obligatoria rectificación a posteriori del Estado español podía revocar derechos concedidos a la población saharaui, como es la nacionalidad española, máxime si tenemos en cuenta que los efectos de esta concesión siguieron siendo visibles décadas después (por ejemplo, pagando pensiones a los funcionarios saharauis jubilados) y que la descolonización, a fecha de hoy, no ha terminado, ya que a la nacionalidad española no le ha sucedido la del Estado saharaui ni la del Estado marroquí, sino más bien una zona de limbo jurídico que es el que tratamos de analizar.

Pues bien, estos antecedentes explican que cuando los saharauis solicitaron en 1998 la nacionalidad española comenzaran recordándole al Tribunal Supremo precisamente estos datos, esta ficción, este actuar como si alguna vez hubiesen sido españoles ("El solicitante saharaui invocó el Decreto del 4 de julio de 1958, que dividía el África Occidental española en dos provincias marítimas de segunda clase, denominadas Ifni y Sáhara español”, T. S.). ${ }^{22}$ Y lógicamente ese pretérito actuar del Estado español hubo de ser justificado por parte del Tribunal Supremo.

Pues bien, esta diferencia de opinión sobre el territorio se trasladó en las dos sentencias a la población, dado que, aunque ambas concedieron la nacionalidad a los saharauis implicados, la sentencia de 1998 de la Sala de lo Civil fue nuevamente más favorable a la tesis de la asimilación completa:

Si el territorio de marras, calificado como español, fue luego considerado no español, según las disposiciones que se dejaron mencionadas, ello no significa que al amparo de la calificación, bajo la que se desarrollaron o tuvieron ocurrencia los hechos determinantes del título, no se produjera una apariencia legitimadora,

22 El solicitante saharaui invocó el Decreto del 4 de julio de 1958, que dividía el África Occidental española en dos provincias marítimas de segunda clase, denominadas Ifni y Sáhara español. Sentencia del Tribunal Supremo, Sala de lo Contencioso-Administrativo, Sección 6a., sentencia del 7 noviembre de 1999, RJ $\backslash 2000 \backslash 849$. 
pese a la anulación posterior de la razón jurídica sustentadora. Como afirma la doctrina, «si se llega a demostrar que quien estaba beneficiándose de la nacionalidad española “iure sanguinis o iure soli”, no era, en realidad español» (en este caso supondría que no tenía la plena nacionalidad), al ser nulo el título de atribución respectivo, no parece justo que la eficacia retroactiva de la nulidad, (recogida «expresis verbis» en la Ley Descolonizadora), se lleve a sus últimas consecuencias en materia de nacionalidad. ${ }^{23}$

El hecho de que los saharauis pudiesen participar en las Cortes españolas de la época mostraba para el alto tribunal que “... se pretendía hacer manifiesta la equiparación de los «stati» entre «españoles peninsulares» y «españoles nativos»". ${ }^{24}$ Así, el Tribunal Supremo viene a afirmar que si los saharauis pasaron de la condición de súbditos a la de españoles indígenas en igualdad de condiciones que el resto, esta condición no se podía perder si a posteriori se deconstruía el Sáhara Occidental. Es decir, si dicho territorio pasaba nuevamente de provincia a colonia, o incluso si nunca llegó a dejar de ser una mera colonia, su población por el contrario sí realizó el tránsito desde la condición de súbditos a la de ciudadanos, por lo que era ilegítimo declarar nula con carácter retroactivo dicha nacionalidad.

Pues bien, la concesión de la nacionalidad a los dos saharauis creó el espejismo, ${ }^{25}$ pronto diluido, de que cien mil saharauis podrían recuperar la nacionalidad española. ${ }^{26}$ Tal cosa no ocurrió, y eso es lo que explica que diez años más tarde los saharauis volvieran a los tribunales espa-

${ }^{23}$ La Ley descolonizadora no dice nada sobre ese tema, pero el caso es que la cita está literalmente copiada de la sentencia del alto tribunal. Seguramente se esté refiriendo al Real Decreto 2258/76, sobre opción de la nacionalidad española por parte de los naturales del Sáhara. Tribunal Supremo (Sala de lo Civil), sentencia núm. 1026/1998 del 28 octubre, $\mathrm{RJ} \backslash 1998 \backslash 8257$.

${ }^{24}$ Idem.

${ }^{25}$ El País, 30 de octubre de 1998, p. 28 (titulares: "Más de cien mil saharauis pueden ser españoles", "Una sentencia del Supremo abre la puerta para que recuperen su antigua nacionalidad”; Ruiz Miguel, Carlos, "Nacionalidad española de ciudadanos saharauis: secuela de una descolonización frustrada (y frustrante)”, Revista General de Derecho, 663, 1999.

${ }^{26}$ La interpretación favorable a la nacionalidad española de los saharauis ha sido compartida por muchos investigadores, por ejemplo, Mercedes Moya, "Atribución de la nacionalidad española y declaración de nacionalidad con valor de simple presunción”. BIB 2007 7719, Aranzadi Civil-Mercantil, núm. 11/2007 (Estudio), Pamplona, Aranzadi, 2007. 
Esta revista forma parte del acervo de la Biblioteca Jurídica Virtual del Instituto de Investigaciones Jurídicas de la UNAM

ñoles, pero esta vez reclamando su condición de apátridas. ${ }^{27}$ Pero para llegar a este tema debemos analizar antes la tercera etapa.

\section{Tercera etapa: descolonización}

La tercera etapa comienza en el contexto de las descolonizaciones de los años sesenta y finaliza a principios de 1976, con la retirada del ejército español del territorio del Sáhara Occidental. En efecto, bajo la presión internacional, España se ve obligada a renunciar a la apropiación del Sáhara (lo que el Tribunal Supremo denomina educadamente "dicotomía entre voluntarismo y realismo jurídico") y su legislación acaba reconociendo sin tapujos que el Sáhara es una colonia. Esta etapa se desarrolla entre finales de 1975 y principios de 1976, en el contexto de la muerte del dictador Francisco Franco, la marcha verde de Hassan, y el definitivo abandono del Sáhara Occidental por parte de los españoles.

Pues bien, si la segunda fase creó un estatuto ambiguo para los saharauis, la tercera añadió todavía más incertidumbre, ya que a la precipitada retirada de España del Sáhara Occidental, con todo lo que ha generado en torno al estatuto internacional del territorio ${ }^{28}$ hay que añadir la publicación de un Real Decreto que permitía a los saharauis optar por la nacionalidad española.

En efecto, en febrero de 1976 España ordena a sus tropas volver a la península, lo que provoca una guerra abierta entre los saharauis y

27 Así, si se contempla el periodo 1988-1993, la mayoría de los peticionarios son latinoamericanos, y los africanos solicitantes son somalíes, etíopes, angoleños y liberianos. Entre 1983 y 1994 hubo en España 12000 solicitudes para ser refugiado. Entrena, Francisco, en varios autores, Los refugiados en España, Instituto Nacional de Servicios Sociales, 1994, pp. 15 y 41 .

En contra de la sentencia del Tribunal Supremo en el caso de 1998 podemos citar a Paz García, "Reconocimiento de nacionalidad española a saharaui nacido en El Aaiún por consolidación. Comentario a la STS (Sala Primera) de 28 de octubre de 1998 (Ponente Sr. Almagro Nosete)", Anuario de Derecho Civil, enero-marzo de 1999, pp. 425-432.

28 Mattew Craven plantea precisamente la complejidad que tiene distinguir entre sucesión y continuidad de Estados, "For all the apparent significance of the distinctions adverted to here, it has become very clear that such forms of differentiation raise more questions than they answer, and that those who continue to employ them do so with a certain hesitancy". Craven, Mattew, The descolonization of international law, Oxford Universtiy Press, 2007, p. 67. 
las tropas marroquíes. En agosto de ese mismo año se publica un Real Decreto que permite a los saharauis optar por ser (¿seguir siendo?) españoles. ${ }^{29}$ El contexto en que se publica, bélico, el desierto, la dificultad de las comunicaciones, la marcha colectiva hacia campos de refugiados, muertos, desaparecidos, etcétera, tienen como consecuencia que de un colectivo potencial de decenas de miles de personas sólo se materialicen veintiún solicitudes. ${ }^{30}$ Dado que se concedió un plazo de un año, el derecho de opción caducó antes de que se aprobara la Constitución Española, cuyo artículo 11.2 establece que ningún español de origen podrá ser privado de la nacionalidad.

Pues bien, a la ya controvertida cuestión de si los saharauis habían sido españoles o no había que añadir la compleja naturaleza de este derecho de opción. Por eso ya en democracia surgieron las preguntas de cuál era la naturaleza de esta posibilidad de elección y, sobre todo, si el derecho de opción podía seguir ejercitándose décadas después, dado que las peculiaridades de la población saharaui podrían aconsejar o legitimar una suspensión de la caducidad del plazo. Estas preguntas explican que el propio Tribunal Supremo, cuando tuvo que dictar sentencia en los casos ya citados sobre la nacionalidad de dos saharauis, se planteara numerosos interrogantes sobre la validez de este decreto preconstitucional, no sólo por cuestiones sustantivas, como la "posible (in)constitucionalidad" de dicha norma o la creación de un "falso o mal llamado derecho a optar", en sus palabras, sino adjetivas, como las carencias formales que afectaban al rango o forma de publicación. ${ }^{31}$ Como afirma Juan Soroeta, ${ }^{32}$ el citado Real Decreto convirtió a los saharauis en realidad en apátridas, ya que no hubo sucesión de Estados y los saharauis eran españoles.

Con estos antecedentes llegamos a la primera década de 2000, el objeto de nuestro trabajo. Los saharauis ya han constatado que no podrán

29 Real Decreto 2258/1976, de 10 de agosto, sobre opción de la nacionalidad española por parte de los naturales del Sáhara.

${ }^{30}$ Guzmán Zapater, Mónica, "Descolonización y nacionalidad. El caso saharaui. (En torno a la STS de 26 de octubre de 1998)", Revista de Derecho Privado, marzo de 2000, pp. 200-210.

${ }_{31}$ Sentencia del Tribunal Supremo, Sala Primera, de 28 de septiembre de 1998, $\mathrm{RJ} \backslash 1998 \backslash 8257$.

32 Soroeta Liceras, Juan, op. cit. 
Esta revista forma parte del acervo de la Biblioteca Jurídica Virtual del Instituto de Investigaciones Jurídicas de la UNAM

obtener la nacionalidad española, por lo que cambian los registros de su lucha solicitando ahora la concesión de la apatridia en suelo español. Tanto la Administración española como la Audiencia Nacional, en primera instancia, deniegan las peticiones y el asunto vuelve otra vez al Tribunal Supremo. Y el alto tribunal falla nuevamente a su favor concediéndoles el estatuto de apatridia, pero se ve obligado a justificar ahora por qué no son españoles, entre otras cosas porque se ve impelido por los propios saharauis. En efecto, en sus expedientes y solicitudes los saharauis muestran con claridad que son conscientes de que la petición de apatridia está relacionada con su expulsión como españoles ("Que tanto su padre (fallecido) como su madre y sus abuelos nacieron en el Sáhara Español, disponiendo en su momento y hasta la ocupación de Marruecos de documentación española (DNI) y afiliación a la Seguridad Social $;{ }^{33}$... que sus padres tenían DNI español $;{ }^{34}$... que llegó a trabajar para el ejército español”, ${ }^{35}$ etcétera). En un caso concreto un saharaui fue más allá y formuló con claridad el problema, que se reconociese que o es español o es apátrida, poniendo en un brete a la administración y a los propios tribunales. Así, solicitaba que:

... se declare ser conforme a derecho la resolución del Ministerio del Interior, confirmándola y declarando expresamente, a meros efectos declarativos que el motivo de denegación del Estatuto de apátrida a Gaspar es que, en base a todo lo alegado, al interesado le corresponde la nacionalidad española. ${ }^{36}$

En ese caso la Audiencia Nacional no respondió a la petición del saharaui, y el Tribunal Supremo, aun cuando reconoció que no era procedente ese silencio, no entró en el fondo del asunto (apátrida vs. español) alegando que la solicitud se había hecho de forma sobrevenida cuando el asunto ya se estaba tramitando. Sin embargo, esta cuestión sobrevuela

\footnotetext{
33 Tribunal Supremo, Sala de lo Contencioso-Administrativo, Sección 3a., sentencia del 14 diciembre 2011; RJ\2012\2749.

${ }_{34}$ Tribunal Supremo, Sala de lo Contencioso-Administrativo, Sección 5a., sentencia del 18 julio 2008 RJ $\backslash 2008 \backslash 6875$.

35 Tribunal Supremo, Sala de lo Contencioso-Administrativo, Sección 5a., sentencia del 28 noviembre 2008, RJ $\backslash 2008 \backslash 7023$

${ }^{36}$ Audiencia Nacional, Sala de lo Contencioso-Administrativo, Sección Quinta, sentencia del 22 diciembre 2004 JUR 2005\218013.
} 
Esta revista forma parte del acervo de la Biblioteca Jurídica Virtual del Instituto de Investigaciones Jurídicas de la UNAM

sobre todos los expedientes, máxime si comprobamos que todos los saharauis que han solicitado la condición de apátridas presentan una serie de características similares. En efecto, si observamos hasta donde nos ha sido posible el contenido de los expedientes podemos constatar que los solicitantes del estatus de apátrida han nacido mayoritariamente en localidades que pertenecían al Sáhara español antes de que el Estado abandonase dicho territorio. Así, Villa Cisneros, ${ }^{37}$ Dajla, ${ }^{38}$ Haouza - Smara - ${ }^{39}$ Aaiún ${ }^{40}$ o Bir Ganduz ${ }^{41}$ son localidades situadas en territorio español antes de que Marruecos invadiera el Sáhara Occidental. Por ello, los saharauis solicitaban ser apátridas a pesar de que nacieron y vivieron en territorio español, aportando en muchos casos incluso documentación acreditativa de su pertenencia a España o de su ascendencia. Junto a esta característica, mayoritaria, hay algún caso aislado de saharauis que han nacido en los campos de refugiados existentes en Argelia, es decir, después de la fecha en que Marruecos invadió el Sáhara y en un lugar distinto, un campo de refugiados, al que habrían nacido en condiciones normales. ${ }^{42}$

Pues bien, en 2007 el Tribunal Supremo da un giro a la posición sostenida casi diez años antes, declarando que los saharauis nunca habían sido españoles, al margen completamente de los sentimientos "de quien, como el actor, aunque indígena del Sáhara, se consideraba plenamente español". ${ }^{43}$ Así, en la primera sentencia que trata el tema en esta segunda etapa, 2007-2012, afirma el tribunal:

${ }^{37}$ Sentencia del Tribunal Supremo del 11 mayo de 2012, RJ $\backslash 2012 \backslash 6667$.

38 Sentencia de la Audiencia Nacional, Sala de lo Contencioso Administrativo, sentencia del 8 de junio de 2011, JUR 2011/223837.

39 Sentencia de la Audiencia Nacional, Sala de lo Contencioso-Administrativo, Sección Quinta, del 20 noviembre 2003 JUR 2004\76953.

Sentencia del Tribunal Supremo, Sala de lo Contencioso-Administrativo, Sección 3a., del 14 diciembre 2011; RJ 2012\2749.

${ }^{40}$ Sentencia del Tribunal Supremo, Sala de lo Contencioso-Administrativo, Sección 3a., del 14 octubre 2011, RJ $\backslash 2012 \backslash 3443$.

${ }^{41}$ Sentencia del Tribunal Supremo, Sala de lo Contencioso-Administrativo, Sección 3a., del 22 junio 2011, RJ $\backslash 2011 \backslash 5524$.

42 Sentencia de la Audiencia Nacional, Sala de lo Contencioso-Administrativo, Sección 5a., del 25 octubre 2005 JUR $2005 \backslash 268772$.

${ }^{43}$ Tribunal Supremo, Sala de lo Contencioso-Administrativo, Sección 5a., Sentencia del 20 noviembre 2007 RJ $2008 \backslash 6615$. 
Por lo que hace referencia, en primer lugar, a la nacionalidad española debemos señalar que, como regla general, en este momento, no puede la misma considerarse de atribución a los saharauis, y, por supuesto que, en concreto, en modo alguno a la recurrente... En resumen, pues, la opción por la nacionalidad española de los saharauis fue una posibilidad a ejercitar por el período de un año y solo para los que reunían las condiciones que en la sentencia que hemos trascrito se señalan. No es, por tanto, una posibilidad actual y viable para la recurrente. ${ }^{44}$

La mala conciencia del Tribunal se puede observar en sus titubeos al afirmar en esa misma sentencia que "(los saharauis) no contaban, como regla general, con la nacionalidad española en el momento de la ocupación de territorio por Marruecos". Nos podemos preguntar qué significa como regla general, ¿implica que la mayoría nunca fue española o que al marcharse la metrópoli del Sáhara Occidental se despojó de la nacionalidad española a los saharauis? ¿Qué valor le concedemos entonces a las anteriores reflexiones de ese mismo tribunal, en particular a la que afirmaba en 1998 que "no parece justo que la eficacia retroactiva de la nulidad (recogida expresis verbis en la Ley Descolonizadora), se lleve a sus últimas consecuencias en materia de nacionalidad"?

En conclusión sobre este punto, los saharauis que han solicitado la condición de apátridas en España han obligado a revisar, una vez más, la naturaleza tanto de la colonización como de la descolonización del Sáhara Occidental, e indirectamente si lo saharauis fueron alguna vez españoles de pleno derecho o meros súbditos. Por ello, podemos afirmar que los saharauis han sido declarados apátridas como consecuencia de un proceso de cosificación, al aplicarles en tanto que seres humanos las mismas reglas que a su territorio en tanto que materia inerte y objeto de comercio e intercambio. Y ello como consecuencia de que el territorio del Sáhara Occidental pasó de la condición de colonia a la de territorio español, y de aquí nuevamente a la de colonia, retirándose España del territorio sin tomar conciencia de los dramáticos efectos que su precipitada marcha generaría en la población nativa; que los saharauis transitaron desde la condición de súbditos a la de nacionales españoles en igualdad de condiciones que los originarios, y de aquí, a la de apátridas; que el Tribunal Supremo sustituyó la posición que consideraba

\section{${ }^{44}$ Idem.}


Esta revista forma parte del acervo de la Biblioteca Jurídica Virtual del Instituto de Investigaciones Jurídicas de la UNAM

injusto anular a posteriori la condición de españoles a los saharauis por la que sostenía que nunca fueron españoles, por lo que en realidad eran apátridas, y, por último, que la Administración española pasó de integrar el Sáhara Occidental en el territorio nacional a desinteresarse por el mismo, de igualar a los saharauis en las Cortes franquistas a revocarles la nacionalidad, y de considerarles españoles indígenas a tratarles como nacionales marroquíes, argelinos o refugiados de la ONU. Es lo que estudiaremos a continuación.

\section{La nacionalidad marroquí}

Posiblemente, de todos los argumentos empleados por la Administración española y la Audiencia Nacional, el más hiriente sea el que afirmaba que los saharauis no eran apátridas porque podían obtener la nacionalidad marroquí. ${ }^{45}$ La exigencia era tan inicua que el Tribunal Supremo la invalidó, pero resulta interesante contrastar la argumentación de la Administración, la Audiencia y el alto tribunal español, porque permite resolver un problema de carácter más universal, y es el de qué ocurre con la población nativa de un determinado territorio cuando es invadido manu militari por un Estado. En este caso, ¿tiene derecho la población a rechazar la nacionalidad que pragmáticamente le pueda ofrecer el ocupante? Lo examinamos a continuación.

Al enfrentarse a esta cuestión, la Audiencia Nacional española contestó que era indiferente si el saharaui quería o no la nacionalidad que se le ofrecía, o si era justo o injusto, dado que lo importante es que si se podía obtener se debía solicitar:

No obstante ello no consta que el interesado que ha nacido en Argelia haya solicitado la nacionalidad argelina y haya recibido una respuesta negativa. Se comprende que el recurrente entienda que no puede considerarse como una posibilidad válida para una persona de origen saharaui el poder optar a la nacionalidad marroquí pues implicaría una renuncia a unos ideales como es la posibilidad de autodeterminación de su pueblo. Pero esas razones no determinan que deba reconocér-

45 Sentencia del Tribunal Supremo, Sala de lo Contencioso-Administrativo, Sección 5a., del 18 de julio de 2008, RJ 2008\6875. 
sele el Estatuto de Apátrida ya que como hemos dicho anteriormente sólo puede ser reconocido como apátrida la persona que no sea considerada como nacional suyo por ningún otro Estado, entendiendo que la imposibilidad deviene no por propia conveniencia del interesado de carecer de la citada nacionalidad, sino que se trata de una imposibilidad jurídica, es decir, que la persona no sea considerada como nacional conforme a la legislación de otro Estado y en este caso tampoco consta que el interesado haya solicitado la nacionalidad marroquí y haya recibido una respuesta negativa. ${ }^{46}$

Imputar a los saharauis la nacionalidad argelina, mauritana o española plantea sus problemas específicos, pero la marroquí presenta una enorme singularidad por la historia propia del Sáhara Occidental. Marruecos y los saharauis se enfrentan en un litigio de carácter internacional desde hace más de tres décadas por la titularidad del territorio, debatiéndose si pertenece a Marruecos,${ }^{47}$ que invadió militarmente dicha zona, o si por el contrario los saharauis tienen derecho a crear su propio Estado independiente. ${ }^{48}$ Es obvio que si los saharauis que viven en los campos de refugiados argelinos solicitan la nacionalidad marroquí se la van a conceder, ya que la asimilación de la población saharaui legitimaría a Marruecos a la hora de reclamar el territorio. Por ello, la afirmación

46 Sentencia de la Audiencia Nacional, Sala de lo Contencioso-Administrativo, del 22 de diciembre de 2004, JUR 2005 218013 y de 17 del 10 de 2007, Sección Quinta, Sala de lo Contencioso-Administrativo revocada después por el Tribunal Supremo, Sala de lo Contencioso-Administrativo, sección 3a., sentencia del 20 de junio de 2011, RJ $\backslash 2011 \backslash 5469$.

${ }^{47}$ En su estudio Shaw muestra las ventajas e inconvenientes que presentan las dos teorías existentes sobre reconocimiento de Estados, la constitutiva y la declarativa. Shaw, Malcom N., International Law, 4a. ed., United Kingdom, Cambridge University Press, p. 297.

48 "It was not just established states that were eager narrowly to define the right of selfdetermination as a right end colonial status. The newly independent states of Africa were keen to erect a breakwater against the spread of secessionist proclivities to subgroups in their territories. And so, with the dawning of decolonization in its continent, the Organization of African Unity adhered to the principle of uti possidetis, developed a century earlier when Latin American states acquired independence from Spain. That principle «upgraded former administrative delimitations, established during the colonial period, to international frontiers», thereby assuring their sanctity as state borders. It also provided a bright line test for assessing claims to self-determination- one that could be rationalized more readily in terms of international stability concerns than of political philosophy”. Steiner, Henry y Alston, Philip, International Human Rights in Context Law, Politics, Moral, 2a. ed., Oxford University Press, 2000, p. 1256. 
Esta revista forma parte del acervo de la Biblioteca Jurídica Virtual del Instituto de Investigaciones Jurídicas de la UNAM

de que "si Marruecos reconoce como nacional suyo al interesado no se aplicaría la Convención (de apatridia)” ${ }^{49}$ no es ingenua ni inocente.

Cuando la Administración española ha atribuido a los saharauis la nacionalidad argelina, mauritana o el estatuto de refugiado con la Minurso, éstos se han limitado a negarla sin entrar en más consideraciones. Sin embargo, en el caso de atribución de la nacionalidad marroquí la reacción ha sido de abierta hostilidad: aun cuando Marruecos estuviese dispuesto a concederles la nacionalidad, los saharauis la rechazan por motivos políticos, ya que consideran que el Estado marroquí detenta ilegítimamente su territorio. Por ello, en los expedientes podemos hallar numerosos comentarios sobre esta negativa a aceptar una asimilación que consideran una modalidad de colonialismo. ${ }^{50}$ Sus argumentos son tajantes: no son marroquíes porque el Sáhara Occidental no pertenece al Estado marroquí:

... y, por otra parte, señaló que no existe resolución alguna de la ONU de la que pueda derivarse que las autoridades marroquíes la reconozcan como marroquí por cuanto - según expresa - el Sáhara Occidental es un territorio en proceso de descolonización, clasificado como Territorio No Autónomo por parte de la ONU, no siendo, en consecuencia, territorio marroquí... ${ }^{51}$ En segundo lugar, indica que la misma carece de inscripción alguna de nacimiento como nacional marroquí, y amén de que Marruecos no está reconocido por el Derecho Internacional como Estado del que forme parte el Sáhara Occidental o antigua Provincia Española del Sáhara. ${ }^{52}$

Junto a esta negativa a la asimilación encontramos al menos un par de referencias a la represión que sufren los saharauis a manos del Estado marroquí:

49 Fallo de la Audiencia Nacional revocado después por la sentencia del Tribunal Supremo, Sala de lo Contencioso-Administrativo, Sección 5a., del 18 de julio de 2008, RJ $2008 \backslash 6875$.

50 Audiencia Nacional, Sala de lo Contencioso Administrativo, sentencia del 8 de junio de 2011, JUR 2011/223837.

51 Tribunal Supremo, Sala de lo Contencioso-Administrativo, Sección Quinta, sentencia del 20 de noviembre de 2007 RJ $2008 \backslash 6615$.

52 Audiencia Nacional, Sala de lo Contencioso-Administrativo, Sección Quinta, sentencia del 20 de noviembre de 2003, JUR 2004\76953. 
Esta revista forma parte del acervo de la Biblioteca Jurídica Virtual del Instituto de Investigaciones Jurídicas de la UNAM

... alegando que carece de nacionalidad argelina y enfatizando la represión que llevan a cabo las autoridades marroquíes contra los saharauis... ${ }^{53}$ la vida de los saharauis se ha vuelto insoportable por la presiones de las autoridades de Marruecos y la falta total de libertad, al no permitirles ni siquiera expresar sus ideas. Las autoridades de Marruecos tienen sus espías que denuncian a los saharauis partidarios de la independencia, se les denuncia y en cualquier momento pueden ser detenidos y encarcelados sin motivos ni garantías procesales ni legales. ${ }^{54}$

Pues bien, esta colusión entre la Administración del Estado y la Audiencia Nacional conllevaría en la práctica que los habitantes de un territorio que ha sido invadido nunca podrían adquirir la condición de apátridas, ya que el Estado invasor, si quiere, y normalmente quiere porque de esa forma legitima la invasión, puede asimilar a los invadidos. Así, la condición de apátrida o no dependería de un acto graciable de un Estado agresor, ocupante o colonizador.

Pues bien, el Tribunal Supremo falló en contra de esta adquisición forzosa de la nacionalidad marroquí a través de tres líneas argumentativas.

La primera es que la nacionalidad no originaria no se puede imponer. Así, para el Tribunal Supremo las personas no están obligadas a adoptar una nacionalidad que les venga impuesta desde fuera, lo que repercute en la condición de apátrida. Por ello, la apatridia no sería el estatus sólo de quien carece de Estado, sino también de quien no quiere pertenecer a un determinado Estado ("en modo alguno, la nacionalidad puede venir determinada por la imposición, por parte de un país, con el que se mantienen determinados vínculos — por variados motivos - en relación con quien no desea dicha nacionalidad"). ${ }^{55}$ Por ello, la nacionalidad establece un vínculo doble, Estado-individuo, que se retroalimenta "en el marco de una relación de voluntariedad y mutua aceptación”. ${ }^{56}$

\footnotetext{
53 Tribunal Supremo, Sala de lo Contencioso-Administrativo, Sección 5a., sentencia del 28 de noviembre de 2008, RJ $\backslash 2008 \backslash 7023$.

${ }^{54}$ Tribunal Supremo, Sala de lo Contencioso-Administrativo, Sección 5a., sentencia del 18 de julio de 2008, RJ $\backslash 2008 \backslash 3455$.

55 Tribunal Supremo, Sala de lo Contencioso Administrativo, sección 3a., sentencia del 27 de abril de 2012, RJ 2012/6407.

${ }^{56}$ Tribunal Supremo, Sala de lo Contencioso-Administrativo, Sección 5a., sentencia del 18 de julio de 2008, RJ 2008\6875.
} 
La segunda es de naturaleza histórica. El Sáhara Occidental no perteneció nunca al Estado marroquí, por lo que los saharauis no son, en defecto o ausencia de otra nacionalidad, nacionales marroquíes. Aunque el Tribunal Supremo insiste en que los saharauis nunca fueron españoles de origen, no por ello infiere que pertenecen al Estado marroquí. Para legitimar esta argumentación el alto tribunal se basa en el dictamen ya citado de la Corte Internacional que establecía que "ni los actos internos ni los internacionales en los que se basa Marruecos indican, en el periodo pertinente, la existencia o el reconocimiento internacional de vínculos jurídicos de soberanía entre el Sáhara Occidental y el Estado marroqui'". ${ }^{57}$

La tercera es de naturaleza política: los saharauis no son marroquíes porque el Estado marroquí invadió militarmente su territorio. Así, aun cuando se reconoce el derecho de la población nativa a optar por la nacionalidad de un Estado que sucede a otro en la posesión de un determinado territorio, este derecho no es una obligación cuando la sucesión es la consecuencia de una ocupación militar, tal y como ha ocurrido en el caso marroquí. ${ }^{58}$

En conclusión, podemos reconducir lo expuesto a dos líneas de argumentos. Por un lado la Administración del Estado y la Audiencia Nacional, a quienes resulta indiferente cómo se obtenga la nacionalidad, esto es, si es impuesta, inicua o aceptada por el beneficiario, ya que lo importante es la posibilidad de obtener una nacionalidad, sea la que sea y como sea ("una cosa es no tener una nacionalidad determinada y otra muy distinta no querer ostentar la que, con razón o sin ella, un Estado quiere atribuirle"); ${ }^{59}$ por otro, el Tribunal Supremo, quien matiza que no basta con obtener una nacionalidad sino que es necesario que la adquisición, cuando se trate de nacionalidades no originarias, sea voluntariamente aceptada por el beneficiario, y que en el caso del Sáhara Occidental Marruecos es un Estado invasor, por lo que no puede además beneficiarse de la aprehensión de los saharauis.

57 Sentencia del Tribunal Supremo, Sala de lo Contencioso-Administrativo, Sección 5a., del 18 de julio de 2008, RJ 2008\6875.

58 Sentencia del Tribunal Supremo, Sala de lo Contencioso-Administrativo, Sección 5a., 20 de noviembre de 2007, RJ 2008\6615.

59 Tribunal Supremo, Sala de lo Contencioso-Administrativo, Sección 3a., sentencia del 21 de octubre de 2011 RJ $\backslash 2012 \backslash 1411$. 
Esta revista forma parte del acervo de la Biblioteca Jurídica Virtual del Instituto de Investigaciones Jurídicas de la UNAM

\section{La nacionalidad saharaui}

La condición de apátrida se puede entender en más de un sentido: a) como persona que carece de nacionalidad, en el sentido de que ningún país reconoce como propia a esa persona (v. gr. persona de la que se desconoce su etnia, tribu, pueblo u origen); $b$ ) como persona que es nacional de un Estado que no es reconocido por otros Estados; c) como persona que tiene una nacionalidad definida (nacionalidad en sentido étnico), pero no quiere o no puede pertenecer a un determinado Estado. ${ }^{60}$

A pesar de que ni la Convención de Nueva York ni la normativa española reconocen estas distinciones, la realidad es que esta tipología conlleva implicaciones importantes a la hora de reconocer la condición de apátrida. En el caso de los saharauis se da la paradoja de que de una forma u otra están a la vez en la segunda y la tercera situación, ya que han creado su propio Estado y a la vez reivindican con orgullo su nacionalidad saharaui, ${ }^{61}$ lo que ha provocado desventajas a la hora de obtener la condición de apátridas en España. Pues bien, siendo este el punto de partida, se plantea el problema de cuál es el estatuto jurídico de una persona que es de nacionalidad, en el sentido étnico, saharaui, pero a la vez su nacionalidad política está condicionada por un reconocimiento parcial de su Estado. ${ }^{62}$

${ }^{60}$ Mercedes Moya, en un estudio sobre los conflictos que presenta España con la concesión de la nacionalidad a los nacidos en excolonias españolas, distingue la nacionalidad como estado civil; como vínculo jurídico y político; como derecho (derecho a tener una nacionalidad); y como criterio para decidir la ley aplicable en materias como la capacidad o los derechos y deberes. Moya Escudero, Mercedes, "Atribución de la nacionalidad española y declaración de nacionalidad con valor de simple presunción.” BIB 2007\719, Aranzadi Civil-Mercantil, núm. 11/2007 (Estudio), Pamplona, Aranzadi, 2007.

61 “... El recurrente solicitó en su día a la Administración que se le reconociese la condición de apátrida en España, respondiendo, a la pregunta de si había tenido en algún momento alguna nacionalidad, que «solo la saharaui que no es reconocida por el Gobierno español» (folio 1.7 del expediente), y alegando más adelante que «no tengo nacionalidad, soy saharaui»”. Tribunal Supremo, Sala de lo Contencioso-Administrativo, Sección 5a., sentencia del 18 de julio de 2008, RJ $\backslash 2008 \backslash 6875$.

${ }_{62}$ En un interesante artículo sobre la inmigración, Mónika Szente-Varga mostraba las dificultades que plantea el no reconocimiento del Estado saharaui. A pesar de la numerosa inmi- 
Esta revista forma parte del acervo de la Biblioteca Jurídica Virtual del Instituto de Investigaciones Jurídicas de la UNAM

A esta cuestión se enfrentó la Audiencia Nacional cuando en una sentencia desestimó la petición de un saharaui para que se le reconociera el estatuto de apátrida. El núcleo de la justificación del fallo fue que había nacido en Argelia y no había demostrado que ese país le denegara expresamente la nacionalidad, y que estaba bajo la protección de la Minurso. Sin embargo, dejó caer un tercer argumento, en el que no profundizó, pero que resulta interesante para nuestro análisis. La tesis es que los saharauis son nacionales del Estado saharaui, por lo que no pueden ser considerados apátridas. En este sentido afirmaba la Audiencia que:

La RASD (República Árabe Saharaui Democrática) proclamada por el Frente Polisario tal como consta en el informe de la CEAR (Comisión Española de Ayuda al Refugiado) ha sido reconocida como Estado soberano e independiente por la Organización para la Unidad Africana (OUA) y por más de 80 países. Ello significa que frente a esos países nunca pueden ser considerados apátridas sino saharauis. De hecho en el certificado de la Delegación Saharaui para España habla de "ciudadanos" saharauis, lo que implica el reconocimiento de esa nacionalidad. España no ha reconocido a la RASD como Estado lo que determina que para España el aquí solicitante no tiene la nacionalidad saharaui. No obstante ello, no se le puede reconocer la condición de apátrida por las siguientes razones... ${ }^{63}$

Así, la cuestión de qué hacer con los nacionales de un Estado que no ha sido reconocido por toda la comunidad internacional lo resuelve la Audiencia taxativamente: los saharauis no pueden ser apátridas en ninguno de los ochenta países que reconocen a la República Saharaui. ${ }^{64}$ Ahora bien,

gración de los saharauis en España y en la propia Europa, no se les puede contabilizar, ya que el censo sólo computa el Estado al que pertenecen los inmigrantes, por lo que los saharauis se computarían como inmigrantes argelinos, marroquíes, o bajo la etiqueta de "otros". SzenteVarga, Mónika, “Una fuerza trasnacional: los saharauis en España”, HAO, núm. 29, otoño de 2012, pp. 117-124.

${ }^{63}$ Sentencia del 22 de diciembre de 2004, dictada por la Sección Quinta de la Sala de lo Contencioso-Administrativo de la Audiencia Nacional, JUR 2005, 218013.

${ }_{64}$ "En uno u otro momento, 83 gobiernos, la mayoría de Asia, África y Latinoamérica, han reconocido la República Saharaui. En la actualidad, sólo unos 50 tienen relaciones diplomáticas permanentes con el gobierno saharaui en el exilio, pero la República Saharaui ha conservado su condición de miembro de la Organización de la Unión Africana (ahora Unión Africana) que obtuvo en 1984.” Dumbar, Charles, ex embajador de Estados Unidos, es pro- 
¿cuál es el estatus de esos mismos saharauis en los países que no reconocen a su Estado? La Audiencia no entra a resolver este problema, ya que en este caso concreto resuelve la sentencia basándose en otras cuestiones (Argelia y la Minurso), pero el problema que crea es bastante grave. Si un saharaui es nacional de la República Saharaui, cuando resida en un país, como es España, que no reconoce a dicha República, se puede encontrar con que el no reconocimiento del Estado lleva implícito el reconocimiento de la condición de nacional del Estado no reconocido, lo que le impide ser apátrida. Es decir, según la Audiencia una persona puede ser a la vez apátrida en unos países y no en otros, y en su extremo más absurdo, nacional de un Estado no reconocido por el mismo país que le niega la condición de apátrida.

Pues bien, esta compleja cuestión no ha sido resuelta por los tribunales españoles, por lo que puede potencialmente volverse a presentar.

\section{La nacionalidad argelina}

Tanto la Administración española como la Audiencia Nacional han considerado que los saharauis eran de nacionalidad argelina y, por lo tanto, no podían obtener el estatuto de apátridas. El núcleo de su argumentación reside en que los saharauis son en la práctica refugiados argelinos y cuando salen de Argelia disponen de pasaporte oficial expedido por dicho Estado. Además, la incipiente administración saharaui colabora en la tramitación de estos pasaportes, lo que constituye una prueba indirecta de su nacionalidad argelina. ${ }^{65}$ Así, la Audiencia Nacional afirmaba que:

... A la luz de la normativa arriba expuesta, se concluye que desde un punto de vista jurídico, apátrida es aquella persona que no puede ser nacional de otro Estado conforme a su legislación. Ello supone que quien solicite dicho estatuto ha de probar que reúne tal requisito. En el caso de autos, el recurrente no lo ha

fesor en la Universidad de Boston. En 1998 fue representante especial de la ONU para el Sáhara Occidental, "Sáhara Occidental: no ignorar a los saharauis", AFKAR/IDEAS, primavera de 2010.

${ }_{65}$ Tribunal Supremo, Sala de lo Contencioso Administrativo, sección 3a., sentencia del 27 de abril de 2012, RJ 2012/6407. 
acreditado, pues se deduce de la documentación constitutiva del expediente (folio 3.1) que, efectivamente, la República de Argelia concede pasaportes ordinarios a los saharauis, de acuerdo con acuerdos de colaboración suscritos por ese país con el FRENTE POLISARIO, residentes en los campamentos de refugiados de la zona argelina de Tindouf, y, en caso de vencimiento de dichos pasaportes, se pueden renovar en la Delegación Saharaui para España (folio 3.2 del expediente). ${ }^{66}$

Es cierto que la mayoría de los saharauis que llegaron a España disponían de pasaporte argelino, pero éstos siempre alegaron ante la Administración española y los tribunales que los pasaportes se concedían única y exclusivamente por motivos humanitarios,${ }^{67}$ para que se les permitiera salir y regresar a los campos de refugiados ${ }^{68}$ o dirigirse a otros países, ${ }^{69}$ pero que en ningún caso suponía una aceptación expresa ni tácita de la nacionalidad argelina. Pues bien, esta cuestión la zanjó el Tribunal Supremo apelando al carácter humanitario de la concesión del pasaporte: este documento se concede para garantizar la salida y la entrada en los campos de refugiados argelinos, pero no implica la concesión de la nacionalidad por parte de la administración argelina. Además, al igual que ocurría con la nacionalidad marroquí, el Tribunal Supremo insistió en que la adquisición de la nacionalidad no originaria es un acto voluntario, y los saharauis expresamente rechazaban la nacionalidad argelina. Por último, y a diferencia de lo que ocurre con Marruecos, "Argelia nunca ha efectuado manifestación alguna — expresa ni tácita — tendente al reconocimiento u otorgamiento de la nacionalidad argelina a los saharauis que, como refugiados, residen en los campamentos de Tinduff". ${ }^{70}$ En conclusión, los saharauis tampoco son argelinos.

${ }_{66}$ Argumento de la Audiencia Nacional, sentencia de 17-10-2007 dictada por la Sala de lo Contencioso-Administrativo de la Audiencia Nacional, Sección Quinta, en otro caso. Tribunal Supremo, Sala de lo Contencioso-Administrativo, sección 3a., sentencia del 20 de junio de $2011, \mathrm{RJ} \backslash 2011 \backslash 5469$.

${ }^{67}$ Sentencia del Tribunal Supremo, Sala de lo Contencioso Administrativo, sección 3a., del 27 de abril de 2012, RJ 2012/6407.

${ }_{68}$ Tribunal Supremo, Sala de lo Contencioso-Administrativo, sección 3a., sentencia del 14 de octubre de 2011, RJ $\backslash 2012 \backslash 3443$.

${ }^{69}$ Sentencia del Tribunal Supremo, Sala de lo Contencioso-Administrativo, sección 3a., del 22 de junio de 2011, RJ $\backslash 2011 \backslash 5524$.

${ }^{70}$ Sentencia del Tribunal Supremo, Sala de lo Contencioso-Administrativo, sección 5a., 
Esta revista forma parte del acervo de la Biblioteca Jurídica Virtual del Instituto de Investigaciones Jurídicas de la UNAM

\section{EL ESTATUTO DE REFUGIADO DE LOS SAHARAUIS}

Para poder comprender la causa por la que se ha estimado que los saharauis no eran apátridas debido a la intervención de la Misión de Naciones Unidas para la Organización del Referéndum en el Sáhara Occidental en 1991, hay que recapitular para distinguir dos conceptos entrelazados, el de refugiados y el de apátridas. En efecto, el artículo 1.1 de la Convención de los Apátridas de 1954 establece que: "A los efectos de la presente Convención el término apátrida designará a toda persona que no sea considerada como nacional suyo por ningún Estado, conforme a su legislación".

Mientras que el artículo 1.2.i) de esa misma Convención establece que su regulación no será aplicable:

i) A las personas que reciban actualmente protección o asistencia de un órgano u organismo de las Naciones Unidas distinto del Alto Comisionado de las Naciones Unidas para los Refugiados, mientras estén recibiendo tal protección o asistencia.

ii) A las personas a quienes las autoridades competentes del país donde hayan fijado su residencia reconozcan los derechos y obligaciones inherentes a la posesión de la nacionalidad de tal país;

Así, en principio una persona es apátrida por defecto, si ningún país lo reconoce como suyo. ${ }^{71}$ Pero eso no es suficiente, ya que además es necesario que no ostente el estatuto de "refugiado", es decir, que no esté protegida por la ONU (que no sea el alto comisionado) ni tenga un estatuto similar al de los nacionales donde reside el potencial apátrida. De esta forma, entre el nacional de un Estado y un apátrida hay un estadio intermedio, la condición de refugiado, que puede dar lugar a situaciones confusas. Los refugiados pueden ser apátridas o ciudadanos de un Estado, mientras que los apátridas pueden ser refugiados o no serlo, de del 18 de julio de 2008, RJ 2008\6875, y sentencia del Tribunal Supremo, Sala de lo Contencioso Administrativo, sección 3a., sentencia del 27 de abril de 2012, RJ 2012/6407.

71 Audiencia Nacional, Sala de lo Contencioso Administrativo, sentencia del 8 de junio de 2011, JUR 2011/223837. 
forma que sólo se consideran apátridas a los efectos de la Convención a los apátridas-no refugiados, es decir, a un subconjunto del conjunto de los apátridas. Pues bien, la situación de los saharauis, residentes en campamentos de refugiados en territorio argelino y bajo la cobertura de una Misión de las Naciones Unidas, esto es, con un "doble refugio", Argelia y la ONU, ha generado muchas dudas.

La resolución número 690 del 24 de abril de 1991, del Consejo de Seguridad de la ONU, creó la Misión de Naciones Unidas para la Organización del Referéndum en el Sáhara Occidental (Minurso), con objeto de garantizar el cese el fuego entre los saharauis y Marruecos y la celebración de un referéndum. Dado que más de veinte años después el referéndum sigue sin celebrarse, podemos afirmar que el objetivo principal de la Minurso ha fracasado. Ahora bien, la cuestión es si esta tutela ejercida por las Naciones Unidas en los campos de refugiados argelinos es equiparable en sus efectos a los que pueda prestar una entidad (Estado o ente internacional) que proteja a un determinado colectivo otorgándoles el estatuto de refugiados (e indirectamente el de no-apátridas).

Por ello, el foco de debate entre la Administración española, la Audiencia Nacional y el Tribunal Supremo se ha centrado en: a) si las funciones asignadas a la Minurso eran equiparables a la "protección o asistencia" que establece el artículo 1.2.i) de la Convención de Apátridas ya examinado; b) si estar bajo la cobertura de la Minurso implica la imposibilidad de ser un apátrida; c) si aun cuando la cobertura de la Minurso conlleve "protección o asistencia", en el sentido del referido artículo 1.2.i), esta cobertura alcanza a los saharauis que estén físicamente en España; d) si, al margen de la Minurso, el hecho de que los campamentos de refugiados se sitúen en Argelia y este Estado dé cierta protección y atención a los saharauis conlleva o no que los saharauis puedan ser considerados refugiados bajo tutela argelina.

Las funciones de la Minurso son muy específicas, ${ }^{72}$ dadas las específicas circunstancias que concurrían en el conflicto del Sáhara en 1991, y

\footnotetext{
72 Primero. Supervisar la cesación del fuego; Segundo. Verificar la reducción de tropas de Marruecos en el Territorio; Tercero. Supervisar la restricción de las tropas de Marruecos y el Frente Polisario a los lugares señalados; Cuarto. Tomar medidas con las partes para asegurar la liberación de todos los prisioneros políticos o detenidos del Sáhara Occidental; Quinto.
} 
Esta revista forma parte del acervo de la Biblioteca Jurídica Virtual del Instituto de Investigaciones Jurídicas de la UNAM

las podemos dividir en dos grupos: a) de naturaleza bélica, con objeto de pacificar la región; $b$ ) de naturaleza política, con objeto de gestar un referéndum. ${ }^{73}$

Pues bien, tanto para la Administración española como para la $\mathrm{Au}$ diencia Nacional las funciones atribuidas a la Minurso imposibilitaban que los saharauis residentes en España obtuvieran la condición de apátridas, ya que éstos no estaban en situación de desprotección. ${ }^{74}$ Así, en la resolución de sus expedientes, la Administración del Estado se centraba en la protección dispensada por Argelia a los saharauis, que les permitía disfrutar "de los elementos esenciales de la protección internacional recogidos en la Convención sobre el Estatuto de los Refugiados, como son la garantía de no devolución, la asistencia material y la expedición de documentos como el pasaporte, que los identifican y les permiten viajar fuera de Argelia y regresar", hasta tal punto que la prueba de que disponían en la práctica de este estatuto de refugiados es que no habían pedido la condición de apátridas en la propia Argelia. ${ }^{75}$ Por su parte, la Audiencia Nacional continuó esta línea de considerar refugiados a los saharauis, pero centrándose en las competencias de la Minurso:

Entiende esta Sala que a la vista de las funciones que desarrolla la MINURSO no se puede aplicar al interesado nacido en el campamento de Tindouf (Argelia) y de origen saharaui la Convención del Estatuto de Apátrida, ya que si bien la misión principal de esa Misión es la celebración de un referéndum del Sáhara Occidental también tiene otros objetivos que se pueden calificar de "protección”, no siendo necesario para excluir su aplicación que además dicha Misión preste servicios de asistencia médica y de desarrollo social y económico ya que el artículo 1.2 i) de la

Supervisar el intercambio de prisioneros de guerra (Comité Internacional de la Cruz roja); Sexto. Hacer efectivo el programa de repatriación (Alto Comisionado de las Naciones Unidas para los refugiados); Séptimo. Identificar y registrar a las personas con derecho a voto; Octavo. Organizar y asegurar la realización de un referéndum libre y justo, y dar a conocer los resultados (Las sentencias del Tribunal Supremo sobre la apatridia atribuyen estas funciones, de forma literal, a la Minurso).

73 Sentencia del Tribunal Supremo, Sala de lo Contencioso-Administrativo, sección 5a., del 18 de julio de 2008, RJ 2008\6875.

${ }^{74}$ Audiencia Nacional, Sala de lo Contencioso Administrativo, sentencia del 8 de junio de 2011, JUR 2011/223837.

75 Sentencia de la Audiencia Nacional del 26 de marzo de 2010, PROV 2010, 124002. 
Convención de Estatuto de apátrida de 28 de septiembre de 1954 excluye la protección "o" asistencia, siendo por tanto suficiente que exista una de las dos funciones (dado que la conjunción es disyuntiva) para que sea aplicable dicho artículo. ${ }^{76}$

Como podemos observar, la Audiencia realiza una interpretación extensiva de las competencias con objeto de encajarlas en la excepción del artículo 1.2.i) de la Convención de Nueva York. Pues bien, en el presente caso el Tribunal Supremo rechazó esta interpretación extensiva, apoyándose en tres líneas argumentativas:

La primera es que las competencias atribuidas a la Minurso son muy específicas, por lo que "No parece, pues, que con tan específicas competencias la citada Misión pueda otorgar a los saharauis la protección y asistencia que la Convención requiere para excluir a los mismos de su pase a la situación de apátrida". ${ }^{77}$ Es decir, las funciones que hipotéticamente se pueden atribuir a la Minurso (asistencia médica o desarrollo económico y social, como decía la Audiencia) no forman parte de su mandato específico, por lo que no cabe equiparar las funciones que de facto se puedan estar desarrollando con las de la excepción de la Convención de Nueva York.

La segunda atiende a la realpolitik: dos décadas después de que se creara la Misión se puede afirmar que ha fracasado y que los saharauis siguen malviviendo en el desierto. Así, afirma el alto tribunal que: "Escasa protección y asistencia puede deducirse de tal Misión por parte de quienes — desde hace más de treinta años — viven como refugiados en el desierto de una país vecino, y sin que el ordenado referéndum se haya celebrado tras los citados dieciséis años de espera". ${ }^{78}$

La tercera es de carácter hermenéutico, e implica que la protección bajo la cobertura de un organismo de la ONU no es equiparable a la nacionalidad concedida por un Estado. En efecto, afirma el Tribunal Supremo que incluso si la protección de la Minurso fuera efectiva, ésta se-

${ }^{76}$ Sentencia de la Audiencia Nacional, Sala de lo Contencioso-Administrativo, sección quinta, del 22 de diciembre de 2004, JUR 2005 218013.

77 Tribunal Supremo, Sala de lo Contencioso-Administrativo, sección 5a., sentencia del 18 de julio de 2008, RJ 2008\6875.

${ }^{78}$ Idem. 
ría sólo en los campos de refugiados argelinos, no alcanzando a España. Por ello, la persona refugiada bajo la cobertura de la ONU deja de ser "no-susceptible de apatridia" cuando por el motivo que sea abandona dicho territorio y marcha a un determinado país, como por ejemplo España. ${ }^{79}$

Pues bien, esta postura la hemos de contrastar con la sostenida en casos similares por elTribunal de Justicia de la Unión Europea. Así, en una sentencia en la que un grupo de apátridas palestinos, que estaba bajo la cobertura de un organismo de la ONU, salía voluntariamente del territorio en el que se prestaba dicha cobertura y se marchaba a Europa para solicitar el Estatuto de Refugiado, se planteó la cuestión de si seguían o no bajo cobertura de un organismo de la ONU, lo que repercutía precisamente en la posibilidad de obtener asilo internacional.

Pues bien, la Gran Sala del Tribunal de Justicia de la Unión Europea estimó que el artículo 12.1.a) de la Directiva europea sobre refugiados establecía que lo relevante no era sólo que un aspirante a obtener el estatuto de refugiado dejara de tener cobertura de un organismo de la ONU, sino que bastaba con que dicho organismo no pudiese cumplir su cometido, lo que abría la posibilidad de solicitar asilo en Europa ${ }^{80}$ En otro caso similar el Tribunal de Justicia de la Unión Europea restringió el ámbito de aplicación de la excepción contenida en el 1.2.i) de la Convención de Apátridas de 1954 (que excluye de la condición de apátrida a quien esté bajo protección de un organismo de la ONU), estimando que no bastaba con la posibilidad de que se pudiera recibir dicha protección, sino que era necesario, para que la excepción fuese de aplicación, que la protección se recibiese efectivamente. ${ }^{81}$ Estas dos interpretaciones son más favorables para los potenciales solicitantes del estatuto de apatridia, ${ }^{82}$ ya que restringen el campo de aplicación de las excepciones contenidas en la Convención de Nueva York.

${ }^{79}$ Sentencia del Tribunal Supremo, Sala de lo Contencioso Administrativo, sección 3a., del 27 de abril de 2012, RJ 2012/6407 y del 20 de noviembre de 2007, Sala de lo ContenciosoAdministrativo, sección 5a., RJ 2008/6615.

${ }^{80}$ Tribunal de Justicia de la Unión Europea, Gran Sala, sentencia del 19 de diciembre de 2012, TJCE $\backslash 2012 \backslash 400$

${ }_{81}$ Tribunal de Justicia de la Unión Europea (Gran Sala), sentencia del 17 de junio de 2010, TJCE $\backslash 2010 \backslash 180$.

${ }^{82}$ Martín Arribas destaca en su estudio cómo antes de la entrada en vigor de las referidas 
Pues bien, esta doctrina del tribunal europeo sería plenamente aplicable a los saharauis. En efecto, siguiendo al Tribunal Supremo español podemos entender que Minurso no puede “cumplir su misión”, dado que veinte años después de que hubiese sido creado no ha logrado organizar un referéndum. A su vez, los saharauis que salgan de los campos de refugiados argelinos deberían poder obtener el estatuto de refugiado en cualquier país de la Unión Europea, dada la interpretación que hace el Tribunal de Justicia de la Unión Europea de la Directiva comunitaria sobre refugiados.

En conclusión sobre este punto, el Tribunal Supremo español revocó los argumentos tanto de la Administración española como de la Audiencia Nacional, declarando que la condición de refugiado que presentan los saharauis en los campamentos de refugiados en Argelia y bajo la protección de la Minurso no implica que ostenten la categoría de refugiados oficiales, lo que impediría el reconocimiento de su condición de apátridas. A la vez, el Tribunal Supremo fue más allá y creó implícitamente una categoría nueva, la de refugiado que no reside dentro de un campo de refugiados. En efecto, en una de las sentencias ya citadas afirmó que lo relevante era que los saharauis estuviesen en España, y no en los campos de refugiados de Argelia, con lo que aun cuando fuesen, en efecto, refugiados en sentido técnico, dejarían de serlo cuando ya no residieran en Argelia bajo la protección de Minurso. Esta línea de argumentación enlaza con la sostenida por el Tribunal de Justicia de la Unión Europea, en el sentido de restringir el ámbito de aplicación de la excepción establecida en el 1.2.i) de la Convención de Apátridas de 1954, lo que permite en definitiva aplicar el estatuto de apátrida a más personas necesitadas de protección.

Directivas, la noción de refugiado que aparecía en la Convención de Ginebra de 1951 otorgaba a los Estados un amplio margen de maniobra desde su derecho interno. Eso provocaba que "las autoridades competentes de los Estados europeos estén interpretando restrictivamente esa noción, a la hora de reconocer el estatuto de refugiado o el derecho de asilo”. Martín Arribas, Juan José, Los Estados europeos frente al desafío de los refugiados y el derecho de asilo, Madrid, Dykinson, 2000, p. 249. 


\section{CUeSTIONES FORMALES}

Los defectos formales son el último recurso del que se ha agarrado la Administración española para denegar la solicitud de la condición de apátridas a los saharauis. Más allá de un casuismo burocrático carente de interés, podemos hallar cuestiones relevantes que atañen a los medios de prueba en contextos de gran dificultad humana, social y económica, como ocurre con los refugiados y los apátridas. Es este el enfoque que pretendemos darle.

\section{Falta de acreditación de la condición de apátrida}

Tanto la Administración española como la Audiencia Nacional han exigido que los solicitantes del estatuto de apátrida acrediten previamente que han solicitado la nacionalidad de un determinado Estado (Argelia, Marruecos, etcétera) y se les ha denegado expresamente. Así, en sus recursos, el abogado del Estado argumentaba que los saharauis debían demostrar que, en efecto, carecían de nacionalidad. Aun cuando admitía que no era necesaria una prueba plena y acabada, estimaba que tampoco bastaba la mera declaración de que se carecía de una nacionalidad, de forma que, siguiendo el principio de que quien afirma algo ha de probarlo, los saharauis debían "aportar algún dato a partir del cual pueda colegirse que efectivamente las cosas son como el solicitante expone". ${ }^{83}$ Siguiendo esta línea, la Audiencia Nacional endureció la carga de la prueba hasta el punto de exigir que los saharauis agotaran las vías administrativas y judiciales para poder demostrar que se carecía de nacionalidad.

A la luz de la normativa arriba expuesta, se concluye que desde un punto de vista jurídico, que es el único que ha de tratar este Tribunal, apátrida es aquella persona que no puede ser nacional de otro Estado conforme a su legislación. Ello supone que quien solicite dicho estatuto ha de probar que reúne tal requisito. En el caso de

83 Tribunal Supremo, Sala de lo Contencioso Administrativo, sección 3a., sentencia del 27 de abril de 2012, RJ 2012/6407. 
autos, la recurrente no lo ha acreditado, pues la misma, como ella ha reconocido, tenía un pasaporte argelino, que posteriormente las autoridades argelinas en España no se lo han renovado, pero, como correctamente se indica en el acto expresamente recurrido, dicha parte no ha probado que haya agotado todas las vías de impugnación existentes en el ordenamiento jurídico argelino a fin de concluir que de forma definitiva no posee la nacionalidad de un país que previamente se la había concedido, y así demostrar la existencia de ese dato esencial de carecer de nacionalidad de otro Estado conforme a su legislación. ${ }^{84}$

La cuestión de fondo, nada desdeñable, es de qué forma demuestra una persona no sólo que carece de nacionalidad, sino que en un momento dado necesita la protección internacional inherente a la justificación de la condición de refugiado, apátrida u otra figura afín.

Pues bien, elTribunal Supremo español, en el caso concreto de los saharauis, rebajó la necesidad de la prueba de la carencia de nacionalidad, hasta el punto de bastar la mera declaración de que se carece de dicha nacionalidad. Así, argumentó que: ${ }^{85}$

... el reconocimiento de la condición de apátrida se presenta como imperativo, bastando para ello la manifestación de la carencia de nacionalidad, y tal carencia de nacionalidad — que la norma reglamentaria que examinamos toma de la Convención de referencia (NA. Se refiere a la normativa española en relación a la Convención del Apátrida) — surge de la circunstancia de que la persona solicitante «no sea considerada como nacional suyo por ningún Estado, conforme a su legislación». Esto es, tampoco de dicha precepto puede deducirse la intensidad probatoria que en la sentencia de instancia se establece que, como sabemos, rechazó la pretensión de la recurrente por no haber agotado las vías administrativas y judiciales argelinas.

${ }^{84}$ Audiencia Nacional, Sala de lo Contencioso-Administrativo, sentencia del 20 de noviembre de 2003, JUR 2004\76953.

85 Tribunal Supremo, Sala de lo Contencioso-Administrativo, Sección 5a., sentencia del 20 de noviembre de 2007, RJ 2008\6615. 
Esta revista forma parte del acervo de la Biblioteca Jurídica Virtual del Instituto de Investigaciones Jurídicas de la UNAM

\section{Solicitudes extemporáneas}

La normativa interna de los países establece plazos para solicitar la condición de refugiado o de apátrida. El problema se plantea con que los plazos pueden ser demasiado cortos si atendemos a las circunstancias particulares de estos colectivos, personas en culturas ajenas con ausencia de recursos económicos y sociales para entender las complejidades burocráticas. Pues bien, éste ha sido el caso español. ${ }^{86}$ Algunos saharauis presentaron la solicitud de apátrida fuera del plazo establecido por la normativa interna española, que es en concreto de treinta días, por lo que de potencial apátrida pasaban a la condición de inmigrante ilegal. Así:

A mayor abundamiento, el interesado ha formulado su solicitud de reconocimiento del estatuto de apátrida llevando más de un mes en situación de ilegalidad, pues llegó a España el 16 de septiembre de 2007 sin que a la finalización de la estancia autorizada en el visado (60 días) su permanencia haya estado amparada por ningún tipo de autorización, por lo que, de conformidad con lo dispuesto en el artículo 4.2 del Reglamento de reconocimiento del estatuto de apátrida (RCL 2001, 1809, 2769), dicha solicitud ha de presumirse manifiestamente infundada, presunción que, por las razones antes señaladas, no ha quedado destruida... ${ }^{87}$

Pues bien, nuevamente el Tribunal Supremo revocó todas estas líneas de argumentación tratando de contextualizar la situación concreta de los saharauis tanto en el mundo como en España. Así, aun reconociendo que la normativa española es estricta en el plazo para realizar la solicitud (un mes desde que se reside en España o, si la situación es sobrevenida, un mes desde que sobrevino la nueva situación), ${ }^{88}$ el alto tribunal alegó

${ }^{86}$ Tribunal Supremo, Sala de lo Contencioso-Administrativo, sección 3a., sentencia del 11 de mayo de 2012 RJ $2012 \backslash 6667$; y Tribunal Supremo (Sala de lo Contencioso-Administrativo, sección 3a., sentencia del 22 de junio de 2011, RJ $\backslash 2011 \backslash 5524$.

${ }_{87}$ Tribunal Supremo, Sala de lo Contencioso-Administrativo, sección 3a., sentencia del 14 de diciembre de 2011, RJ $\backslash 2012 \backslash 2749$.

${ }^{88}$ Artículo 4 del Real Decreto 865/2001, de 20 de julio, por el que se aprueba el Reglamento de reconocimiento del estatuto de apátrida. 
que la extemporaneidad no implica estrictamente que se desestime automáticamente la petición, sino que se presumirá que es infundada. Esta presunción iuris tantum permitiría a los saharauis presentar la solicitud en cualquier momento, si bien con la obligación de demostrar la condición de apátrida si la solicitud se efectuaba fuera del plazo, treinta días, establecida por la normativa interna española. Además, aplicando la ley sobre asilo, si en el expediente constaba que el solicitante estaba siendo perseguido, la presunción de que la solicitud era infundada ni siquiera entraría en juego. ${ }^{89}$

Lo más relevante de esta interpretación es la flexibilización, en la práctica por motivos humanitarios, de los plazos y formalidades exigibles por la normativa interna para presentar una solicitud de apatridia, en consonancia con la necesidad de protección internacional de los colectivos afectados por estas situaciones.

\section{Discrecionalidad}

La opcionalidad establecida en el Decreto de 1976, ya analizada, reapareció nuevamente en el derecho español, afectando a la problemática que estamos estudiando. En efecto, la Ley de Extranjería de 2000 (Ley 4/2000) traspasó la opcionalidad de los saharauis a la Administración española, de forma que era el Estado el que se arrogaba la posibilidad de conceder discrecionalmente el estatus de apátrida o no. ${ }^{90}$ Así, no bastaba con ser apátrida para obtener dicha condición, ya que la concesión era graciable, opcional, voluntaria por parte del Estado español. Todo ello a pesar de que el Estatuto de Apátridas que firmó España no concedía esa discrecionalidad a los Estados: una persona es apátrida desde que se demuestre, lo que obliga al Estado donde resida a actuar en consecuencia sin que sea una facultad potestativa.

El carácter irregular del poder que el Estado se confería a sí mismo se manifiesta en el hecho de que dicha posibilidad, la discrecionalidad en

${ }^{89}$ Tribunal Supremo, Sala de lo Contencioso-Administrativo, sección $3^{\text {a }}$, sentencia del 14 de octubre de 2011, RJ $\backslash 2012 \backslash 3443$.

90 Artículo 31 de la Ley Orgánica 4/2000, de 11 de enero, RCL 2000\72, sobre los Derechos y Libertades de los Extranjeros en España y su Integración Social. 
Esta revista forma parte del acervo de la Biblioteca Jurídica Virtual del Instituto de Investigaciones Jurídicas de la UNAM

la concesión de la apatridia, estuviese vigente menos de un año, en concreto, desde el 1 o. de febrero de 2000 hasta el 22 de enero de 2001. ${ }^{91}$ En efecto, la Ley 8/2000 modificó el precepto citado de la ley de extranjería y eliminó la opcionalidad hasta ese momento vigente, sustituyendo la expresión "podrá reconocer" por la expresión "reconocerá la condición de apatridia”. Sin embargo, esa posibilidad de discrecionalidad, aunque sólo estuviese vigente unos cuantos meses, caló tanto en la Administración española como en la judicatura, hasta el punto de que la posibilidad de negar la condición de apátrida, aun cuando incluso se demostrase que se carecía de patria, fue alegada por el Estado español en varias ocasiones en los casos que estamos analizando.

Tuvo que ser el Tribunal Supremo el que en casación recordase que la opcionalidad establecida por el artículo 31 de la Ley de Extranjería había sido derogada meses después de que se crease, por lo que a los saharauis les bastaba con demostrar que eran apátridas para ser reconocidos como tales, sin que el Estado pudiese ejercitar el derecho de opción. Así confirmaba el alto tribunal el cambio de paradigma:

... la regulación originaria de la Ley Orgánica 4/2000 viene caracterizada por: a) la necesidad de que el extranjero acredite que el país de su nacionalidad no le reconoce la misma; b) el carácter potestativo de la concesión del Estatuto de Apátrida ("podrá"). En cambio, tras la modificación introducida por la Ley 8/2000 no se exige al extranjero la acreditación de que el país de su nacionalidad no le reconoce la misma, pues la norma se refiere ahora a los extranjeros que "manifiesten" carecer de nacionalidad; y, por otra parte, nos encontramos con un régimen que no es ya potestativo sino imperativo, al señalar el precepto que el Ministro del Interior "reconocerá" la condición de apátridas y les "expedirá" la documentación prevista en la Convención sobre el Estatuto de Apátridas. ${ }^{92}$

En conclusión sobre este punto, las cuestiones formales han sido el último recurso empleado por la Administración española para impedir que

91 Ley Orgánica 8/2000, de 22 de diciembre, RCL 2000\2963, Reforma de la Ley Orgánica 4/2000, de 11-1-2000 (RCL 2000\72 y 209), sobre derechos y libertades de los extranjeros en España y su integración social.

92 Tribunal Supremo, Sala de lo Contencioso Administrativo, sección 3a., sentencia del 27 de abril de 2012, RJ 2012/6407. 
los saharauis adquiriesen el estatuto de apátrida en España, exigiendo en algunos casos imposibles administrativos, como es la prueba diabólica de que se carece de nacionalidad, y en otros arrogándose derechos, como la opcionalidad de la concesión, que hacían inviables las solicitudes.

\section{LAS DIRECTIVAS EUROPEAS}

España forma parte de la Unión Europea, por lo que debe adaptar su derecho interno al contenido de las Directivas que emanan de dicha entidad supranacional. Pues bien, en 2004 la Unión Directiva publicó la Directiva 2004/83/CE, del 29 de abril, tratando de dar un tratamiento homogéneo a las personas necesitadas de protección internacional en Europa, dada la enorme variabilidad existente en los Estados europeos sobre dicha materia. ${ }^{93}$ En diciembre de 2011 se dictó la Directiva 2011/95/UE, que completó la anterior y estableció como fecha límite para que los Estados adaptaran su derecho interno hasta el 31 de diciembre de 2013. Ambas serían de aplicación al caso saharaui.

El problema es que estas bien intencionadas Directivas ${ }^{94}$ se encuadran en un marco internacional más amplio, el de las Convenciones de Refugiados y Apátridas de 1951 (Ginebra) y 1954 (Nueva York), respectivamente. La superposición de las dos Convenciones y las dos Directivas revela, más que un tratamiento homogéneo de la cuestión, una cierta

93 Martín Arribas destaca en su estudio cómo en los años noventa del siglo pasado se fueron creando en la Unión Europea distintos instrumentos para armonizar las diferencias de los Estados europeos en materia de asilo, dado que “... cabe sostener que existen relevantes discrepancias e, incluso, sustanciales contradicciones que afectan a las bases mismas que sostienen los diversos elementos que conforman la definición que establece la convención de Ginebra de 1951 y del protocolo de Nueva York de 1967”. Martín Arribas, Juan José, Los Estados europeos frente al desafío de los refugiados y el derecho de asilo, Madrid, Dykinson, 2000, pp. 159 y ss., y 243.

94 Michael Dummett explica en su estudio "cómo España, Portugal y Grecia, Italia hacen poca distinción entre inmigrantes propiamente dichos y buscadores de asilo; es casi imposible conseguir que una petición de asilo sea aceptada. Hasta 1989, Italia sólo reconocía a los europeos del este como refugiados". Dummett, Michael, Sobre inmigración y refugiados, Título original: On Immigration and Refugees, trad. de Miguel Ángel Coll, Cátedra, 2004, p. 156. 
sensación de desconcierto e inseguridad jurídica, precisamente lo menos oportuno para los colectivos necesitados de protección internacional.

Así, si comparamos la evolución histórica del concepto de refugiado y la del de apátrida, podemos observar cómo el primero ha sufrido una evolución sumativa, es decir, ha ido abarcando cada vez más colectivos sin que estos sean excluyentes entre sí. Sin embargo, la evolución del concepto de apátrida ha sido más bien confusa, al crearse, a medida que se consensuaban nuevos instrumentos internacionales, sentidos diversos e incluso antagónicos.

En efecto, en la Convención del Refugiado de 1951 se definen los apátridas como las personas que: “... careciendo de nacionalidad y hallándose, a consecuencia de tales acontecimientos, fuera del país donde antes tuviera su residencia habitual, no pueda o, a causa de dichos temores, no quiera regresar a él”.

Tres años después se crea la Convención del Apátrida, añadiendo un matiz de carácter restrictivo para los apátridas: “... el término «apátrida» designará a toda persona que no sea considerada como nacional suyo por ningún Estado, conforme a su legislación”.

Este matiz conlleva una notable repercusión por lo siguiente. La Convención del Refugiado establece que un apátrida es la persona que "carece de nacionalidad", de forma que el único dato relevante es la ausencia de ciudadanía, por lo que es indiferente si esa carencia de nacionalidad es voluntaria o no, justificada o no. Pero la Convención del Apátrida cede el protagonismo a los Estados: si los Estados no consideran nacional suyo a una persona, entonces esta persona es apátrida, pero previamente hay que excluir que un determinado Estado, "conforme a su legislación”, considere o no a una persona ciudadana suya. Ya hemos visto la relevancia de esta cuestión en el caso saharaui.

Pues bien, ninguna de las dos directivas de la Unión Europea citadas, a pesar de las numerosas precisiones que contienen, definen qué es un apátrida, por lo que no resuelven el conflicto creado por la Convención del Refugiado y la del Apátrida. Se limitan a afirmar que:

... «refugiado»: un nacional de un tercer país que, debido a fundados temores a ser perseguido por motivos de raza, religión, nacionalidad, opiniones políticas o pertenencia a determinado grupo social, se encuentra fuera del país de su 
nacionalidad y no puede o, a causa de dichos temores, no quiere acogerse a la protección de tal país, o un apátrida que, hallándose fuera del país donde antes tuviera su residencia habitual por los mismos motivos que los mencionados, no puede o, a causa de dichos temores, no quiera regresar a él, y al que no se aplica el artículo 12.

Por si la ausencia de definición no fuera ya en sí misma una carencia, se ha aumentado la inseguridad al crear una categoría de apátridas nuevos, los “apátridas por motivos humanitarios”. En efecto, la Directiva 2004/83, en su considerando noveno, establece que:

Los nacionales de terceros países o los apátridas a los que se autorice a permanecer en el territorio de un Estado miembro por motivos que no sean la necesidad de protección internacional, sino por compasión o por motivos humanitarios y sobre una base discrecional, no están incluidos en el ámbito de aplicación de la presente Directiva.

Es decir, la Directiva excluye expresamente a los apátridas que carezcan de la necesidad de "protección internacional” del ámbito de aplicación de la misma, pero nos plantea la pregunta de a quién se refieren. Así, hasta ahora hemos distinguido a los apátridas "refugiados", que son los perseguidos, de los "no refugiados", que son aquellos a los que se aplica stricto sensu la Convención de los Apátridas dado que también necesitan protección internacional, de ahí que se les otorgue dicho estatuto. Por eso, la distinción "apátridas con necesidades de protección internacional" versus "apátridas sin necesidad de protección internacional” que establece la Directiva europea nos sume en la perplejidad. Además, los apátridas "sin necesidad de protección internacional" pueden obtener el estatuto de apátridas en un país de la Unión Europea "por compasión o por motivos humanitarios". El paternalismo inherente a la "compasión” (podían haber empleado otra palabra, como la solidaridad) se queda corto si constatamos que en ese caso la posibilidad de obtener el estatuto de apátrida es "discrecional", es decir, que es opcional acoger o no a un apátrida.

Por si no hubiera suficientes categorías, las dos Directivas europeas han creado la categoría de "personas con derecho a protección subsidia- 
Esta revista forma parte del acervo de la Biblioteca Jurídica Virtual del Instituto de Investigaciones Jurídicas de la UNAM

ria”, una figura a medio camino entre el refugiado y el no refugiado. Así, una "persona con derecho a protección subsidiaria" es un:

... nacional de un tercer país o apátrida que no reúne los requisitos para ser refugiado, pero respecto del cual se den motivos fundados para creer que, si regresase a su país de origen o, en el caso de un apátrida, al país de su anterior residencia habitual, se enfrentaría a un riesgo real de sufrir alguno de los daños graves definidos en el artículo 15, y al que no se aplican los apartados 1 y 2 del artículo 17, y que no puede o, a causa de dicho riesgo, no quiere acogerse a la protección de tal país;

Por ello, una persona tiene derecho a "protección subsidiaria" si no cumple con los requisitos para ser refugiado (esencialmente, ser perseguido por motivos étnicos, políticos, etcétera) pero está en alguna de estas situaciones:

a) la condena a la pena de muerte o su ejecución, o

b) la tortura o las penas o tratos inhumanos o degradantes de un solicitante en su país de origen, $\mathrm{o}$

c) las amenazas graves e individuales contra la vida o la integridad física de un civil motivadas por una violencia indiscriminada en situaciones de conflicto armado internacional o interno.

La figura no puede ser más confusa. Por lo pronto, no deja de ser llamativo que una persona pueda estar en alguna de estas situaciones y no entre dentro de la categoría de refugiado. Es cierto que para ser refugiado hay que ser perseguido por motivos étnicos, políticos, etcétera, pero los colectivos afectados se han extendido hasta incluir grupos sociales o causas relacionadas con el género, por lo que resulta realmente difícil que una persona pueda ser "condenada a muerte, torturada, sometida a trato inhumano o gravemente amenazada" sin que entre en alguna de las categorías previstas para el estatuto de refugiado. Además, el criterio establecido por elTribunal de Justicia de la Unión Europea para que una persona deje de ser refugiada, y eventualmente pueda ser considerada entonces persona con necesidades de protección subsidiaria, es muy tenue. Así:

Para llegar a la conclusión de que ya no tiene fundamento el temor del refugiado a ser perseguido, las autoridades competentes, a la luz del artículo 7, apartado 2, de 
Esta revista forma parte del acervo de la Biblioteca Jurídica Virtual del Instituto de Investigaciones Jurídicas de la UNAM

La Directiva ( LCEur 2004, 3082), deberán verificar, en relación con la situación individual del refugiado, que el agente o agentes de protección del país tercero de que se trate han tomado medidas razonables para impedir la persecución; que, de este modo, disponen, en particular, de un sistema judicial eficaz para la investigación, el procesamiento y la sanción de acciones constitutivas de persecución, y que el nacional interesado tendrá acceso a dicha protección en caso de que cese su estatuto de refugiado... el eventual cese del estatuto de refugiado se produce sin perjuicio del derecho de la persona afectada a solicitar que se le conceda el estatuto que confiere la protección subsidiaria... ${ }^{95}$

Pero donde más se puede constatar la oscuridad de estas situaciones es en el caso de los apátridas, ya que resulta difícil imaginar que un apátrida pueda entrar en la categoría de "persona con derecho a la protección subsidiaria” sin que a la vez entre potencialmente en la categoría de "refugiado".96

En definitiva, coexisten las figuras de apátridas refugiados y apátridas no refugiados; apátridas necesitados de protección internacional y apátridas no necesitados de protección internacional, y apátridas con necesidades de protección subsidiaria y apátridas sin necesidad de protección subsidiaria.

En 2009 el Tribunal Europeo condenó a España por no adaptar la normativa interna a la Directiva de refugiados de 2004. ${ }^{97}$ Este retrasoomisión-incumplimiento impidió a los tribunales españoles aplicar estas categorías de la Unión Europea a los saharauis, hasta el punto que el propio Estado español tuvo que reconocer que su derecho interno no hacía

95 Tribunal de Justicia de la Unión Europea (Gran Sala), sentencia del 2 de marzo de 2010, TJCE $\backslash 2010 \backslash 47$.

${ }_{96}$ La Organización para la Unidad Africana, en su Convención aprobada en 1969, extendió "la consideración de refugiados a todas aquellas personas obligadas a abandonar su país a causa de una agresión exterior, una ocupación, una dominación extranjera o de acontecimientos que perturben de manera grave el orden público en el país de residencia o nacionalidad". Rodríguez Ugarte, Juan José et al., La situación de los refugiados en España, Madrid, Alianza, 1995, p. 112.

${ }_{97}$ Tribunal de Justicia de las Comunidades Europeas (Sala Quinta). Caso Comisión de las Comunidades Europeas contra España, Sentencia de 9 de julio de 2009, TJCE $\backslash 2009 \backslash 218$. España lo hizo justo en ese año mediante la Ley del derecho de asilo y de la protección subsidiaria, Ley 12/2009, del 30 de octubre (RCL 2009/2051). 
Esta revista forma parte del acervo de la Biblioteca Jurídica Virtual del Instituto de Investigaciones Jurídicas de la UNAM

superflua esta adaptación. Por decirlo con otras palabras, la no transposición de la normativa europea a la normativa interna española perjudicó a los saharauis. España también tiene que adaptar su derecho interno a la Directiva de la misma temática de 2011 antes de diciembre de 2013.98 Es de prever que nos volverán a condenar.

En conclusión, es obvio que, dada la situación de permanente violación de los derechos humanos de los saharauis, tanto individual como colectivamente, éstos deberían poder obtener al menos el estatuto de refugiado, de apátrida o de persona con necesidades de protección subsidiaria en cualquier país europeo, ya que la situación en el Sáhara Occidental, invadido por Marruecos, no permite hablar de un sistema judicial eficaz. ${ }^{99}$ Máxime si observamos que la jurisprudencia del Tribunal de Justicia de la Unión Europea afirma que "la existencia de amenazas graves e individuales contra la vida o la integridad física del solicitante de protección subsidiaria no está supeditada al requisito de que éste aporte la prueba de que está afectado específicamente debido a elementos propios de su situación personal”. ${ }^{100}$

Ahora bien, si este es el marco europeo, actúe o no el Estado español, ¿qué es o debe ser un saharaui para la Unión Europea? Es decir, si un saharaui pide protección internacional en cualquier país de la Unión Europea enarbolando como justificación el contenido de la jurisprudencia del Tribunal Supremo español, ¿cuál será su estatus?, ¿en qué medida la jurisprudencia del Tribunal Supremo español vinculará o servirá de punto de referencia a los tribunales de otros países europeos o incluso al de la Unión Europea? ¿Cuál de las confusas categorías y subcategorías citadas se les aplicaría? Son preguntas de difusa y azarosa respuesta.

98 Si un país no adapta la normativa interna en el plazo adecuado, entonces “... el órgano jurisdiccional nacional que debe interpretarlo está obligado a hacer todo lo posible, a la luz de la letra y de la finalidad de la Directiva, para conseguir el resultado que ésta pretende alcanzar...”, Tribunal de Justicia de las Comunidades Europeas (Gran Sala), caso Meki Elgafaji y otros contra Staatssecretaris van Justitie, sentencia del 17 de febrero de 2009; TJCE \2009\33.

99 La situación de los derechos humanos de los saharauis se puede leer en el apartado cinco, "Los derechos humanos a la sombra de la Berma", del estudio de Rosa Riquelme sobre el Sáhara. Riquelme Cortado, Rosa, "Marruecos frente a la (des)colonización del Sáhara Occidental”, Anuario Mexicano de Derecho Internacional, vol. XIII, 2013, pp. 205-265.

100 Tribunal de Justicia de las Comunidades Europeas (Gran Sala), caso Meki Elgafaji y otros contra Staatssecretaris van Justitie, sentencia del 17 de febrero de 2009; TJCE \2009\33. 


\section{CONCLUSIONES}

Las conclusiones que podemos formular son las siguientes:

1) Al conceder la apatridia a los saharauis, el Tribunal Supremo español ha tratado de reparar mediante mecanismos jurídicos un conflicto de naturaleza política. Aunque este tipo de acciones no forma parte de sus competencias, su laxa interpretación de la normativa sólo nos puede empujar en esta dirección conclusiva. Tanto el Tribunal Supremo como la Audiencia Nacional española están formados por los magistrados de más antigüedad y preparación del país. La enorme discordancia entre las sentencias de la Audiencia, contrarias sin variación a las peticiones de los saharauis, y las del Supremo, favorables a la apatridia, sólo pueden hallar explicación desde las variables no jurídicas, aquellas no mensurables ni comprobables pero que de forma intuitiva o por la mera experiencia todos los agentes jurídicos conocen de su existencia. En comparación, el Tribunal Supremo ha mostrado mayor sensibilidad que la Audiencia al efectuar una interpretación más humanitaria de la situación de los saharauis, aunque para ello haya tenido que forzar no pocas veces la interpretación de las normas nacionales e internacionales. Por otro lado, una sentencia de este tipo, la concesión de la apatridia a los nacionales de un Estado, la República Árabe Saharaui Democrática, cuyos miembros están refugiados bajo cobertura de la ONU en suelo argelino, sólo podía concederse en España, siendo impensable en otro país europeo, ${ }^{101}$ y únicamente puede comprenderse a la luz de la etapa de provincialización que hemos narrado brevemente y de la precipitada huida de la colonia en el contexto del tránsito de la dictadura a la democracia. El resultado es que se ha conseguido reparar, aunque sea mínimamente, y dada la inacción de los poderes públicos estatales en este tema, un conflicto de naturaleza política, ya que el estatuto de apatridia es lo que más se acerca en sus beneficios a la concesión o reconocimiento de la nacionalidad española a los saharauis.

101 Como recuerda Fungairiño, la República Árabe Saharaui Democrática tiene representación cuasidiplomática en la ONU y en la propia Unión Europea. Fungairiño Bringas, Eduardo, "Los saharauis y la nacionalidad española", El mundo, 17 de agosto de 2011. 
Esta revista forma parte del acervo de la Biblioteca Jurídica Virtual del Instituto de Investigaciones Jurídicas de la UNAM

2) Las aportaciones que estimo más relevantes de las citadas sentencias, aparte de la concesión de la apatridia, son: a) la posibilidad de conceder la apatridia a nacionales de un Estado si éste no es reconocido por toda la comunidad internacional; b) la reafirmación de que un Estado no puede imponer por la fuerza la nacionalidad a los habitantes de un territorio, como ha ocurrido con Marruecos; c) restringir el concepto de refugiado para que no impida la concesión de la apatridia; d) atender a la realidad de los hechos, prescindiendo de la veracidad jurídica, en este caso la del derecho internacional, cuando se trata de cuestiones de derechos humanos, y e) la que estimo más paradójica, posibilitar que los saharauis nacidos en el Sáhara Occidental antes de 1975 puedan volver a intentar solicitar la nacionalidad española, dado que tanto la normativa nacional ${ }^{102}$ como la internacional tratan de limitar o restringir la existencia de apátridas. ${ }^{103}$

102 El fiscal Fernando Gómez, por ejemplo, encuentra posible justificar, a partir de las sentencias de apatridia que hemos examinado y de la actual redacción del artículo 17.c del Código Civil español ("son españoles de origen los nacidos en España de padres extranjeros, si ambos carecieran de nacionalidad o si la legislación de ninguno de ellos atribuye al hijo una nacionalidad"), que toda la población saharaui nacida en el Sáhara durante el periodo colonial debería poder acceder a la nacionalidad española de origen por la vía del citado artículo. Para ello sólo bastaría afirmar que los nacidos en el Sáhara Occidental durante la permanencia española han nacido en España. De esta forma, los 74000 saharauis incluidos en el censo español de 1974, que puedan probar su nacimiento en el Sáhara Occidental y que carezcan de nacionalidad, deberían poder solicitar la nacionalidad española de origen. Como recuerda el citado fiscal, el objetivo del citado artículo es evitar situaciones de apatridia en España. Por nuestra parte podemos concluir que con ello tendríamos la paradójica consecuencia de que las sentencias de apatridia han vuelto a abrir la posibilidad de pedir la nacionalidad española a los saharauis. Gómez Recio, Fernando, "Sobre la nacionalidad española de los naturales del Sáhara”, Actualidad Administrativa, núm. veinte, 16 al 30 de noviembre de 2009, t. 2, La Ley.

103 Como recuerda en su trabajo Marina Vargas, el derecho a la nacionalidad es un derecho humano, y la tendencia del derecho internacional es restringir la existencia de la apatridia, creando para ello marcos que posibiliten que los habitantes de un Territorio No Autónomo posean la nacionalidad del Estado sucesor o del antecesor. Por ello, resalta cómo el artículo primero del proyecto de la ONU de 1997 no distinguía entre nacionales metropolitanos y nacionales no de origen o naturalizados (lo que en nuestro caso acarrearía el derecho de los saharauis a tener una nacionalidad aunque nunca hubiesen sido nacionales españoles metropolitanos), y además, el llamado Estado predecesor tiene obligación de asegurarse de que los habitantes del territorio que deja de ser colonia tengan al menos una nacionalidad. Vargas Gómez-Urrutia, Marina, "La nacionalidad de las personas naturales en relación con la sucesión de Estados”, Boletín Jurídico de la Universidad Europea de Madrid, núm. 1, 1998. El objeto de 
3) La concesión del estatuto de apatridia se ha producido en el contexto de la primera década de 2000, una época caracterizada en el país por una mirada al pasado con objeto de reparar los aspectos más oscuros de su historia. A esta etapa pertenecen la Ley de la Memoria Histórica, ${ }^{104}$ que pretendía convertir en asunto público la exhumaciones de las decenas de miles de muertos que hay en España de la época de la Guerra Civil y la posguerra; el juicio en el propio Tribunal Supremo al juez Garzón sobre el caso de las fosas comunes, ${ }^{105}$ que replanteó el problema de la prescripción de los crímenes contra la humanidad en suelo español; la periódica aparición en la prensa de la apertura de fosas comunes en diferentes lugares del país, cercenadas ahora por la crisis financiera, reabriendo una y otra vez heridas; la creación o consolidación de tímidos esfuerzos por conceder la nacionalidad a los descendientes de sefardíes, moriscos o de republicanos españoles expatriados, etcétera. La propuesta del que fuera fiscal jefe de la Audiencia Nacional, Eduardo Fungairiño, de modificar la normativa para que se concediera la nacionalidad con más facilidad a los descendientes de sefardíes, iberoamericanos y saharauis, estableciendo una analogía para nada baladí entre estos colectivos, ${ }^{106}$ forma parte de esta sensibilización colectiva, no sólo académica, hacia los conflictos no resueltos de nuestra historia. Pues

su trabajo fue realizar un análisis sucinto del Proyecto de Artículos que la Asamblea General de las Naciones Unidas aprobó en su 49o. periodo de sesiones, finalizado en julio de 1997. Hemos de añadir nosotros que el proyecto de artículos de la comisión de Derecho Internacional de 1999, sobre "Nacionalidad de las personas naturales en relación con la sucesión de Estados”, se incorporó como Anexo a la Resolución 55/153, de 12 de diciembre de 2000; y por último, que la Resolución 59/34 de la Asamblea General de 2 de diciembre de 2004 (Distr. General 16 de diciembre de 2004), reiteró su invitación a los Estados para que impidieran la apatridia como consecuencia de la sucesión de Estados. Dado que en el caso saharaui, como hemos estudiado, resulta impensable que adquieran la nacionalidad marroquí, la única manera de impedir la apatridia de conformidad con el derecho internacional es concederles la nacionalidad del Estado antecesor, es decir, de España.

104 Ley de la Memoria Histórica, Ley 52/2007, del 26 de diciembre.

105 Sentencia 101/2012 del Tribunal Supremo sobre los denominados "juicios de la verdad", del 27 de febrero de 2012.

106 En concreto, su propuesta está formulada en estos términos: "Se me ocurre que la solución sería tan sencilla como sustituir la actual redacción del artículo 22.1 del Código Civil por esta otra: «Para la concesión de la nacionalidad por residencia se requiere que ésta haya durado 10 años. Serán suficientes cinco años para los que haya obtenido la condición de refugiado y dos años cuando se trate de nacionales de origen de países iberoamericanos, 
bien, esta es la época que contextualiza, y de alguna manera explica y justifica, las sentencias del Tribunal Supremo español en el caso saharaui, unos años caracterizados por un constante goteo de noticias en los medios de comunicación, de libros y artículos académicos, de congresos y jornadas, y de pleitos en los tribunales, que de alguna manera tratan de lidiar con un pasado colonial y fratricida que se resiste a ser sepultado.

4) Al conceder la apatridia, el Tribunal Supremo ha removido la versión oficial o dominante de la descolonización del Sáhara Occidental. En efecto, en principio, y conforme al derecho internacional, el citado territorio nunca formó parte del territorio español, sus habitantes nunca fueron españoles de pleno derecho, y actualmente es un territorio en proceso de descolonización. En el polo opuesto a la tesis mayoritaria se sitúa la versión de que el Sáhara Occidental llegó a formar parte del territorio español, que sus habitantes fueron españoles de pleno derecho, y que dicho territorio fue simplemente abandonado, revocándose a posteriori y por la vía de los hechos consumados la nacionalidad en su momento concedida. Esta es la tesis de los saharauis y, si bien no se ajusta al derecho internacional, al fin y al cabo es la versión de los que perdieron, y la pregunta una vez más es la de quién escribe la historia. Pues bien, la enorme casuística que han presentado las demandas resueltas por la $\mathrm{Au}$ diencia Nacional y el Tribunal Supremo ha obligado a revisar numerosas lagunas y puntos oscuros en la interpretación oficial. Así, el Tribunal Supremo no apoya esta segunda versión, la de los saharauis, pero tampoco se puede afirmar que siga la primera, la mayoritaria. Para poder conceder la apatridia el alto tribunal se ha visto obligado a remover una y otra vez los mismos hechos y la interpretación jurídica de los mismos, obteniendo como resultado una nebulosa, con párrafos claramente contradictorios, que se prestan a múltiples interpretaciones. Por otro lado, el alto tribunal no cita prácticamente ninguna de las numerosas resoluciones que ha dictado la ONU sobre el tema, pero lógicamente no cabe inferir por ello que las desconoce, más bien que las obvia, ya que atiende sobre todo a la realidad de los hechos, no a la forma en que los tratadistas los interpretan. El ejemplo más paradigmático es su opinión

Andorra, Filipinas, Guinea Ecuatorial o Portugal, de sefardíes o de saharauis». Esto sería lo justo”. Fungairiño Bringas, Eduardo, op. cit. 
sobre la Minurso. Si después de casi dos décadas no ha logrado convocar un referéndum sobre el Sáhara Occidental el Supremo deduce que dicho organismo internacional ha fracasado en su misión. No espera a que la ONU dicte una resolución reconociendo el fiasco, simplemente lo afirma en sus sentencias, coincida o no con la comunidad internacional. Incluso llega a afirmar que el territorio está "ya descolonizado". Se podría afirmar también que conforme al derecho internacional el Tribunal Supremo yerra en sus interpretaciones, pero para los saharauis lo único que puede importar al fin y al cabo es lo que sostenga la última instancia judicial española. El caso es que son apátridas porque el alto tribunal español no asume indubitadamente la versión oficial, dominante o mayoritaria, y tampoco ha tratado de compatibilizar sus sentencias con las resoluciones de la ONU. El caso analizado sería una versión jurídica del galileico "Eppur si muove".

5) Las sentencias del Tribunal Supremo ofrecen un escenario incierto para los saharauis residentes en los campos de refugiados en Argelia, escenario que se abre aún más si recordamos que España forma parte de la Unión Europea y que las referidas resoluciones judiciales pueden tener una incidencia obvia fuera del territorio español. Se nos plantean numerosas preguntas y líneas futuras de investigación, ¿podrían solicitar los saharauis el estatuto de apátrida incluso sin salir de los campos de refugiados?, ¿podrían pedir dicho estatuto en cualquier país de la Unión Europea?, ¿cómo conciliar las categorías creadas por las directivas europeas con las sentencias españolas, que fueron dictadas antes de que se adaptara el derecho español a las mismas?, ¿en qué medida las tesis del alto tribunal español, que prescinde de formulismos y de posiciones políticamente correctas, son extrapolables a otros conflictos internacionales?, etcétera. Son cuestiones que habrá que acometer en un futuro inmediato.

6) Por último, lo ocurrido en España debe llevarnos a reflexionar sobre la interrelación entre el derecho internacional y los ordenamientos jurídicos nacionales. La concesión de la apatridia a los saharauis por parte del Tribunal Supremo ha prescindido completamente del derecho internacional, en el sentido de que si las sentencias coinciden con éste, bien, pero si no, para nada frenaba las resoluciones judiciales. Los comentarios ya citados sobre la Minurso o sobre si el Sáhara Occidental 
Esta revista forma parte del acervo de la Biblioteca Jurídica Virtual del Instituto de Investigaciones Jurídicas de la UNAM

está en proceso de descolonización o no demuestran claramente esta forma de actuar. Las enormes interrogantes que estas sentencias suscitan son una muestra de esta falta de coincidencia entre el derecho nacional interno español y la forma en que deberían tratarse estas cuestiones conforme al derecho internacional. Las Directivas de la Unión Europea sólo añaden complejidad a una temática de por sí confusa y en constante movimiento. El caso saharaui demuestra que la realidad va siempre por delante del derecho, y sólo será cuestión de tiempo que nos volvamos a encontrar con sorpresas, cuando un saharaui reivindique la nacionalidad española en, por ejemplo, algún país de la Unión Europea, y un tribunal afirme que se considera competente por ser una cuestión de justicia material, o porque se violaron los derechos humanos del pueblo saharaui, o porque establezca analogías con la imprescriptibilidad de los crímenes contra la humanidad, o porque encuentre una discriminación de origen étnico en la revocación de su nacionalidad, o porque la actuación del Estado español ha creado decenas de miles de apátridas... Quizá no esté lejos el día en que una demanda colectiva de miles de saharauis solicitando la nacionalidad española llegue al Tribunal Europeo de Derechos Humanos.

En definitiva, la Unión Europea se mueve entre los valores más avanzados y la mala conciencia, los derechos humanos y el pragmatismo, y la legislación más progresista del planeta y la amnesia. De un lado se es consciente de que gran parte de los problemas que afectan a los refugiados y a los apátridas son consecuencia del colonialismo europeo, lo que genera una sensación de deuda moral que se sublima a través de preámbulos normativos grandilocuentes ${ }^{107}$ ("España ha pasado a ser un país de acogida de refugiados", SAR don Juan Carlos). ${ }^{108}$ De otro, se teme que

107 Así, el primer considerando de la Directiva (LCEur 2004, 3082) establece que: «Una política común en el ámbito del asilo, incluido un sistema europeo común de asilo, es uno de los elementos constitutivos del objetivo de la Unión Europea de establecer progresivamente un espacio de libertad, seguridad y justicia abierto a los que, impulsados por las circunstancias, busquen legítimamente protección en la Comunidad».

108 Discurso del rey don Juan Carlos de 21 de octubre de 1987, poco después de que España se adhiriera a la Convención sobre Refugiados, INSERSO (Instituto Nacional de Servicios Sociales), Ministerio de Asuntos Sociales, Los refugiados: dinámica de su desplazamiento, Informe de la Comisión Independiente sobre Asuntos Humanitarios Internacionales, trad. de Elvira Pérez, Secreteriat of the Independent Commission on International Humanitarian Issues, 1989, p. 8. 
Esta revista forma parte del acervo de la Biblioteca Jurídica Virtual del Instituto de Investigaciones Jurídicas de la UNAM

un reconocimiento demasiado explícito de este pecado original provoque migraciones masivas. Entre uno y otro lado, el orgullo herido de las viejas potencias coloniales que observan atónitas cómo la historia se niega a quedar sepultada en el limbo. ${ }^{109}$ Por último, y en nuestro caso concreto, el caso saharaui rememora hechos pretéritos autóctonos como las expulsiones de los moriscos y judíos en su día, cuestiones que con relativa frecuencia reaparecen recordándonos quiénes somos y de dónde venimos. ${ }^{110}$ En el caso de estos colectivos se está intentando conceder la nacionalidad española a sus descendientes, en un loable esfuerzo por conciliar nuestra historia. Parece que en el caso de los saharauis se ha comenzado por lo contrario, por concederles la apatridia. La pérdida de la nacionalidad española no fue una cuestión simbólica ni posmoderna, sino material, sustancial, que afectó a la calidad y esperanza de vida de decenas de miles de personas, al privarse a dos generaciones de saharauis del acceso a la universalización de la sanidad y la educación que lograron en estas últimas cuatro décadas el resto de españoles, así como de la movilidad del espacio europeo. Esperemos que no haya que esperar, otra vez, quinientos años o una guerra civil para terminar de asimilar nuestro pasado.

109 En un informe de ACNUR sobre la situación de los refugiados en el mundo en 1995, los saharauis no aparecen por ningún sitio. Eso es estar en el limbo. Rodríguez Ugarte, Juan José (dir.); Amorós, Mario et al. (coords.), ACNUR, (Alto Comisionado de las Naciones Unidas para los Refugiados), La situación de los refugiados en el mundo, Madrid, Alianza, 1995.

110 "Ves que las autoridades españolas despliegan mil y una martingalas tipo cedazo, para que el mayor número posible de presuntos solicitantes de asilo y refugio queden desenmascarados como vulgares "inmigrantes económicos" y se ven desprovistos, por tanto, de todo derecho a invocar motivos de persecución o discriminación política, religiosa, social, racial, sexual, etcétera, que podrían fundamentar una solicitud para legalizar su estancia en este país que está a salvo", Bayón, Miguel, "Información y refugiados, ojos para no ver”, en Rodríguez Ugarte, Juan José et al., La situación de los refugiados en España, Madrid, Alianza, 1995, p. 267. 